\title{
Optical properties of atmospheric fine particles near Beijing during the HOPE- $\mathrm{J}^{3} \mathrm{~A}$ campaign
}

\author{
Xuezhe Xu ${ }^{1,2,3}$, Weixiong Zhao ${ }^{1,2}$, Qilei Zhang ${ }^{1,2,3}$, Shuo Wang ${ }^{1,2,3}$, Bo Fang ${ }^{1,2}$, Weidong Chen $^{5}$, Dean S. Venables ${ }^{6,7}$, \\ Xinfeng Wang ${ }^{8}$, Wei Pu ${ }^{9}$, Xin Wang ${ }^{9}$, Xiaoming Gao ${ }^{1,2,4}$, and Weijun Zhang ${ }^{1,2,4}$ \\ ${ }^{1}$ Key Laboratory of Atmospheric Composition and Optical Radiation, Anhui Institute of Optics and Fine Mechanics, \\ Chinese Academy of Sciences, Hefei 230031, Anhui, China \\ ${ }^{2}$ Laboratory of Atmospheric Physico-Chemistry, Anhui Institute of Optics and Fine Mechanics, Chinese Academy of \\ Sciences, Hefei, 230031, Anhui, China \\ ${ }^{3}$ Graduate School, University of Science and Technology of China, Hefei, 230026, Anhui, China \\ ${ }^{4}$ School of Environmental Science and Optoelectronic Technology, University of Science and Technology of China, Hefei, \\ 230026, Anhui, China \\ ${ }^{5}$ Laboratoire de Physicochimie de l'Atmosphère, Université du Littoral Côte d'Opale, 59140 Dunkerque, France \\ ${ }^{6}$ Department of Chemistry and Environmental Research Institute, University College Cork, Cork, Ireland \\ ${ }^{7}$ Leibniz Institute for Tropospheric Research, 04318 Leipzig, Germany \\ ${ }^{8}$ Environment Research Institute, Shandong University, Jinan, 250100, China \\ ${ }^{9}$ Key Laboratory for Semi-Arid Climate Change of the Ministry of Education, College of Atmospheric Sciences, \\ Lanzhou University, Lanzhou, 730000, China
}

Correspondence to: Weixiong Zhao (wxzhao@aiofm.ac.cn) and Weijun Zhang (wjzhang@aiofm.ac.cn)

Received: 17 September 2015 - Published in Atmos. Chem. Phys. Discuss.: 27 November 2015

Revised: 13 May 2016 - Accepted: 13 May 2016 - Published: 26 May 2016

\begin{abstract}
The optical properties and chemical composition of $\mathrm{PM}_{1.0}$ particles in a suburban environment (Huairou) near the megacity of Beijing were measured during the HOPE$\mathrm{J}^{3} \mathrm{~A}$ (Haze Observation Project Especially for Jing-Jin-Ji Area) field campaign. The campaign covered the period November 2014 to January 2015 during the winter coal heating season. The average values and standard deviations of the extinction, scattering, absorption coefficients, and the aerosol single scattering albedo (SSA) at $\lambda=470 \mathrm{~nm}$ during the measurement period were $201 \pm 240,164 \pm 202$, $37 \pm 43 \mathrm{Mm}^{-1}$, and $0.80 \pm 0.08$, respectively. The average values for the real and imaginary components of the effective complex refractive index (CRI) over the campaign were $1.40 \pm 0.06$ and $0.03 \pm 0.02$, while the average mass scattering and absorption efficiencies (MSEs and MAEs) of $\mathrm{PM}_{1.0}$ were 3.6 and $0.7 \mathrm{~m}^{2} \mathrm{~g}^{-1}$, respectively. Highly time-resolved air pollution episodes clearly show the dramatic evolution of the $\mathrm{PM}_{1.0}$ size distribution, extensive optical properties (extinction, scattering, and absorption coefficients), and intensive optical properties (SSA and CRI) during haze forma-
\end{abstract}

tion, development, and decline. Time periods were classified into three different pollution levels (clear, slightly polluted, and polluted) for further analysis. It was found that (1) the relative contributions of organic and inorganic species to observed aerosol composition changed significantly from clear to polluted days: the organic mass fraction decreased from 50 to $43 \%$ while the proportion of sulfates, nitrates, and ammonium increased strongly from 34 to $44 \%$. (2) Chemical apportionment of extinction, calculated using the IMPROVE algorithm, tended to underestimate the extinction compared to measurements. Agreement with measurements was improved by modifying the parameters to account for enhanced absorption by elemental carbon (EC). Organic mass was the largest contributor $(52 \%)$ to the total extinction of $\mathrm{PM}_{1.0}$, while EC, despite its low mass concentration of $\sim 4 \%$, contributed about $17 \%$ to extinction. When the air quality deteriorated, the contribution of nitrate aerosol increased significantly (from $15 \%$ on clear days to $22 \%$ on polluted days). (3) Under polluted conditions, the average MAEs of EC were up to 4 times as large as the reference MAE value for freshly 
generated black carbon (BC). The temporal pattern of MAE values was similar to that of the $\mathrm{OC} / \mathrm{EC}$ ratio, suggesting that non-BC absorption from secondary organic aerosol also contributes to particle absorption.

\section{Introduction}

Atmospheric aerosols have significant effects on climate forcing (Ramanthan et al., 2001; Anderson et al., 2003; Wang et al., 2010; Bahadur et al., 2012), environment (Cao et al., 2013; Huang et al., 2014), and human health (Nel, 2005; S. Zheng et al., 2015). Visibility is regarded as an indicator of air quality and is affected by the scattering and absorption of solar light by fine particles (Watson, 2002). Uncertainties in atmospheric visibility are mainly due to the uncertainties associated with the aerosols' optical properties, which depend on the physical and chemical properties of atmospheric aerosol, including chemical composition, size distribution, mixing state, morphology, and hygroscopic properties. Understanding how these physical and chemical characteristics affect the optical properties of particles is key to improving quantitative estimates of direct radiative forcing and determining the environmental effects of particles. To ascertain the relationships between these parameters, many research campaigns have been performed during the past decade, including ACE-1 (Bates et al., 1998), ACE-2 (Raes et al., 2000), INDOEX (Eldering et al., 2002), ACE-Asia (Quinn, 2004; Doherty et al., 2005), PRIDE-PRD2004 (Zhang et al., 2008), MILAGRO (Marley et al., 2009), CAREBeijing (Jung et al., 2009; Garland et al., 2009; Wu et al., 2011), and CalNex (Cahill et al., 2012; Thompson et al., 2012; Ryerson et al., 2013; X. Zhang et al., 2013).

Rapid urbanization and economic development has brought about serious environmental problems in the megacities of China (L. Han et al., 2015). The North China Plain (NCP) region in northeastern China has one of the highest global aerosol concentrations (Sun et al., 2013) due to the dense population, the large number of vehicles, and intense industrial activity. The China National Ambient Air Quality Standard designates a daily average concentration of $\mathrm{PM}_{2.5}$ greater than $75 \mathrm{\mu g} \mathrm{m}^{-3}$ as harmful to health. However, $\mathrm{PM}_{2.5}$ concentrations in China often grossly exceed this limit - for instance, daily average mass concentration of $\mathrm{PM}_{2.5}$ in January 2013 were higher than $500 \mu \mathrm{g} \mathrm{m}^{-3}$ for Beijing (Andersson et al., 2015). A large amount of atmospheric pollutants are emitted from fossil fuel, biomass burning, and urban construction (Lei et al., 2011; Zhang et al., 2011). The mixture of these various emissions results in complex physical, chemical, and optical properties of aerosols in the NCP region.

In recent years, many campaigns have been conducted in Beijing (Liu et al., 2013; Sun et al., 2013, 2015; Guo et al., 2014; Andersson et al., 2015; B. Han et al., 2015; Wang et al., 2015; Wu et al., 2016; Xu et al., 2011; X. J. Zhao et al., 2013;
G. J. Zheng et al., 2015). It is worth noting that atmospheric dynamic processes differ between polluted and cleaner periods and that secondary aerosols have been proposed as the major contributor to haze formation (Quan et al., 2014; Sun et al., 2014). Research in the Pearl River Delta of China has shown that submicron particles contribute more than $90 \%$ of the particle extinction (Cheng et al., 2008). However, few studies in the NCP region have focused on the contribution of submicron aerosol to light extinction under different air pollution conditions. Moreover, the evolution of intensive optical properties (effective complex refractive index (CRI) and single scattering albedo (SSA or $\omega$ ), the ratio of scattering to extinction) in haze formation, development, and decline has rarely been reported. Comprehensive studies of intensive optical properties and light apportionment are necessary for a better understanding of the evolution of aerosol physical and optical properties in the NCP.

In this paper, we report continuous measurements of the optical properties, particle size distributions, and chemical composition of submicron aerosol at a suburban site (Huairou) from 16 November 2014 to 11 January 2015. The effective CRI for $\mathrm{PM}_{1.0}$ particles were retrieved with Mie theory by treating the submicron aerosols as spherical particles. The fractional contribution of the chemical components of particles to the total extinction coefficient were calculated by the modified IMPROVE algorithm (Pitchford et al., 2007). $\mathrm{PM}_{1.0}$ optical properties, chemical compositions, size distributions, chemical apportionment of light extinction, and mass scattering efficiencies (MSEs) and mass absorption efficiencies (MAEs) are reported for three different pollution levels.

\section{Experimental}

The Haze Observation Project Especially for Jing-Jin-Ji (Beijing-Tianjin-Hebei, the national capital region of China) Area $\left(\right.$ HOPE- $\mathrm{J}^{3} \mathrm{~A}$ ) field campaign took place at the Huairou campus of the University of Chinese Academy of Sciences $\left(40^{\circ} 24^{\prime} 24.45^{\prime \prime} \mathrm{N}, 116^{\circ} 40^{\prime} 32.95^{\prime \prime} \mathrm{E}\right)$ from October 2014 to January 2015 . The goal of the HOPE- $\mathrm{J}^{3} \mathrm{~A}$ campaign was to better understand the emissions, transport, and evolution of atmospheric fine particles and their precursors in the JingJin-Ji area. Figure 1 shows the map of NCP and the average distribution of the MODIS (MODerate-resolution Imaging Spectroradiometer) (Chu et al., 2003) AOD (aerosol optical depth) with a resolution of $0.2^{\circ} \times 0.2^{\circ}$ during the field campaign from 16 November 2014 to 11 January 2015. The Huairou observation site (marked as a red star in Fig. 1) is situated about $60 \mathrm{~km}$ northeast of Beijing city center and is mainly surrounded by medium density residential suburban areas.

The instruments were installed on the fourth floor of Teaching Building 1, with the sample inlet about $2.5 \mathrm{~m}$ above the roof. The inlet consisted of a $\mathrm{PM}_{1.0}$ ambient size cut 


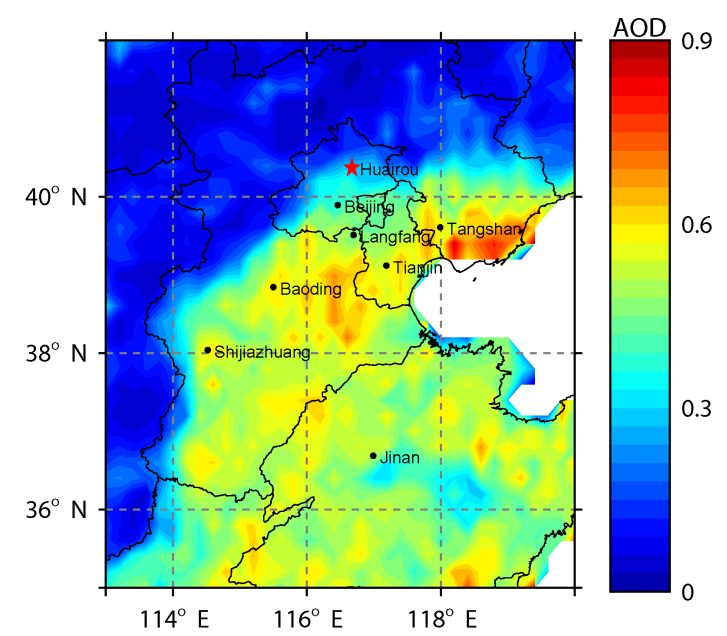

Figure 1. The map of the North China Plain. The observation site (Huairou) is marked with red star. The contour plot represents the average distribution of the MODIS AOD with $0.2^{\circ} \times 0.2^{\circ}$ resolution during the campaign (16 November 2014 to 11 January 2015).

(SF-PM $1.0,1.0 \mathrm{~m}^{3} \mathrm{~h}^{-1}$, Sven Leckel Ingenieurburo GmbH) with a $50 \%$ cut point at $1.0 \mu \mathrm{m}$. Downstream of the inlet, the sample air was dried to below $15 \%$ relative humidity by a diffusion dryer and then passed through a copper tube $(6 \mathrm{~m}$ long with an inner diameter of $1 \mathrm{~cm})$ at a flow rate of $16.7 \mathrm{~L} \mathrm{~min}^{-1}$.

The particle size distribution between 14 and $662 \mathrm{~nm}$ was measured every 3 min with a scanning mobility particle sizer (SMPS, TSI 3936), which comprised an electrostatic classifier (TSI 3080) and a condensation particle counter (TSI 3776). Diffusion losses and the effect of multicharged particles were corrected by the instrument software. The SMPS was validated with laboratory-generated, NIST traceable monodispersed polystyrene latex (PSL) spheres with diameters of $203 \pm 5 \mathrm{~nm}$ (Thermo Scientific 3200A) and $296 \pm 6 \mathrm{~nm}$ (Thermo Scientific 3300A) before and after the campaign (W. Zhao et al., 2013). The measured particle sizes and the certified diameters of the PSL spheres agreed to within $2 \%$.

The optical properties of $\mathrm{PM}_{1.0}$ particles were measured with a newly developed cavity-enhanced albedometer (Zhao et al., 2014a). The albedometer was based on a blue light-emitting-diode (LED) incoherent broadband cavityenhanced absorption spectroscopy (IBBCEAS) system that incorporated an integrating sphere (IS). This instrument is a new tool for direct, in situ, and simultaneous measurement of aerosol scattering and extinction coefficients (and thus of the absorption coefficient and aerosol SSA, $\omega_{470}$ ) at a mean wavelength of $470 \mathrm{~nm}$. The performance of the cavity-enhanced albedometer was previously evaluated using laboratory-generated, monodisperse standard aerosol particles, and the scattering measurements were also found to be in close agreement with TSI 3563 nephelometer measurements (Zhao et al., 2014a, b).

The advantage of broadband over single wavelength measurements is its capacity to simultaneously measure multiple species present in the sample (gases and particles) using a single instrument. A spectral-fitting algorithm was applied from 445 to $480 \mathrm{~nm}$ to retrieve gas concentrations based on their spectral structure and thereby to remove the contribution of gas phase absorption from the aerosol extinction. The scattering signal in the IS was measured by a single channel photomultiplier tube (PMT), providing an integrated result over a narrow bandwidth of $\sim 9 \mathrm{~nm}$ (full-width at half maximum) in the spectral region of $465-474 \mathrm{~nm}$. Truncation reduction tubes (Varma et al., 2003) were used to minimize the forward and backward truncation angles to $1.2^{\circ}$.

The sample volume of the system was about $1.8 \mathrm{~L}$ and the flow rate of the cavity-enhanced albedometer was $1.5 \mathrm{~L} \mathrm{~min}^{-1}$ at atmospheric pressure. The acquisition time for each measurement was $9 \mathrm{~s}$ (for a $1.5 \mathrm{~s}$ integrating time per spectrum, and six-spectra averaging). The temperature and relative humidity of the sample were measured with a hygrometer (Rotronic, model HC2 humidity sensor). The cavity was flushed with dry zero air every hour to acquire a reference spectrum. The reference spectrum was used both in the IBBCEAS retrieval (Fiedler et al., 2003) and to remove the contribution of light scattering from internal surfaces and Rayleigh scattering. The mirror reflectivity $R(\lambda)$ and the scaling factor $\left(K^{\prime}\right.$, the calibration coefficient that related instrument response to scattering magnitude) for the scattering channel of the albedometer were determined by $\mathrm{He}, \mathrm{N}_{2}$, and $\mathrm{CO}_{2}$ every week. No deterioration of $R$ and $K^{\prime}$ were observed during the campaign.

The detection limits for the scattering and extinction channels with $9 \mathrm{~s}$ integration time were 0.54 and $0.15 \mathrm{Mm}^{-1}$, respectively. The total uncertainty in the extinction measurement was estimated to be less than $4 \%$ and arose from uncertainties in the mirror reflectivity $(R)(\sim 1 \%)$, the ratio of cavity length to the cell length containing the air sample when the cavity mirrors were purged $\left(R_{\mathrm{L}}\right)(\sim 3 \%)$, and particle losses in the system $(\sim 2 \%)$. The total uncertainty in the scattering measurement was about $3 \%$, with dominant contributions from uncertainties in the experimentally determined scattering calibration coefficient $\left(K^{\prime}\right)(2 \%)$, and the uncertainty associated with particle losses in the cavity (2\%).

Based on a Mie scattering calculation, the truncated fraction of total scattering was about $0.22 \%$ for a $1 \mu \mathrm{m}$ diameter spherical particle with a CRI of $m=1.6+i 0$ at $\lambda=470 \mathrm{~nm}$. This truncation effect was therefore negligible compared to the measurement uncertainty and no correction for the truncation underestimate was applied to our data.

Potential uncertainties associated with changes in the instrument environment were considered but found to be unimportant. The instrument was located in a temperaturecontrolled room, the temperature inside the albedometer enclosure was maintained at $28.3 \pm 0.8^{\circ} \mathrm{C}$, and the sample flow 
was controlled with a mass flow meter. Example data of the transmitted intensity measured with the CCD (charge coupled device) spectrometer and the scattering signal measured with the PMT are shown in Fig. S1 in the Supplement. The cavity was flushed with particle-free air every hour to acquire the $I_{0}(\lambda)$ spectrum. No obvious drift in the LED light intensity was observed even after $6 \mathrm{~h}$ of measurement, indicating the high stability of the instrument under these operating conditions.

Another $\mathrm{PM}_{1.0}$ sampler (SF-PM 1.0 , Sven Leckel Ingenieurburo $\mathrm{GmbH}$ ) was installed on the roof of the building ( $\sim 20 \mathrm{~m}$ above the ground) to collect $\mathrm{PM}_{1.0}$ samples with quartz filters (47 mm, MUNKTELL Corporation) for offline aerosol chemical composition analysis. The flow rate was 16.7 $\mathrm{L} \mathrm{min}^{-1}$ and samples were collected over the period of 16 November 2014 to 11 January 2015. The collection time period was $12 \mathrm{~h}$ : from 08:30 to 20:30 LT (local time) for daytime samples and from 20:30 to 08:30 LT for nighttime samples. Before sampling, the quartz-fiber filters were preheated for $4 \mathrm{~h}$ at $600^{\circ} \mathrm{C}$ in a muffle furnace, and 10 filters were used as field blank samples in the sampling period. In total, 114 filters were collected; these were stored at $-4^{\circ} \mathrm{C}$ to prevent evaporation of volatilized species until they were analyzed.

A punch of $1.5 \mathrm{~cm}^{2}$ was taken from each filter and then heated in inert and oxidizing atmospheres to volatilize and combust the loaded carbon, respectively. The carbon (elemental carbon, EC, and organic carbon, OC) concentrations were determined with a thermal/optical transmittance aerosol carbon analyzer (Sunset Laboratory, Inc.) (NIOSH, 1996). The measurement principle and operation of the Sunset aerosol carbon analyzer were presented in a previous study (Peterson and Richards, 2002). Another punch with a area of $2 \mathrm{~cm}^{2}$ was taken from the rest of filter, extracted into $10 \mathrm{~mL}$ of deionized water $(>18 \mathrm{M} \Omega$ ) via $20 \mathrm{~min}$ sonication, filtered using a $0.22 \mu \mathrm{m}$ PTFE syringe filter, and stored in a refrigerator at $4{ }^{\circ} \mathrm{C}$ until chemical analysis. Eight water-soluble ion compositions (three anions: nitrate $\left(\mathrm{NO}_{3}^{-}\right)$, sulfate $\left(\mathrm{SO}_{4}^{2-}\right)$, and chloride $\left(\mathrm{Cl}^{-}\right)$; five cations: ammonium $\left(\mathrm{NH}_{4}^{+}\right)$, sodium $\left(\mathrm{Na}^{+}\right)$, potassium $\left(\mathrm{K}^{+}\right)$, magnesium $\left(\mathrm{Mg}^{2+}\right)$, and calcium $\left(\mathrm{Ca}^{2+}\right)$ ) were determined using a Dionex ICS-90 Ion Chromatography system with AS14A and CS14A columns and eluents of $\mathrm{NaCO}_{3}-\mathrm{NaHCO}_{3}$ and methanesulfonic acid, respectively. Further details on this analysis are given elsewhere (X. F. Wang et al., 2013).

Meteorological parameters, including wind speed and direction, temperature, and relative humidity, were continuously recorded at the observation site. The mass concentration of $\mathrm{PM}_{2.5}$ for the air quality classification and concentrations of pollutant gases $\left(\mathrm{SO}_{2}, \mathrm{NO}_{2}, \mathrm{O}_{3}\right.$, and $\mathrm{CO})$ were monitored by the National Environmental $\mathrm{Bu}$ reau and the data at Huairou were retrieved from the Internet (http://113.108.142.147:20035/emcpublish/). In this work, the $\mathrm{PM}_{2.5}$ pollution level was divided into three categories according to the technical regulation on Am- bient Air Quality Index (National Environmental Protection Standard of the People's Republic of China, HJ 633-2012) (http://kjs.mep.gov.cn/hjbhbz/bzwb/dqhjbh/ jcg_fbz/201203/W020120410332725219541.pdf; A. Zhang et al., 2013; G. J. Zheng et al., 2015): clear day $\left(\mathrm{PM}_{2.5}\right.$ concentration $\leq 35 \mu \mathrm{g} \mathrm{m}^{-3}$, when the corresponding individual air quality index (IAQI) of $24 \mathrm{~h}$ averaged $\mathrm{PM}_{2.5}$ concentration ranged from 0 to 50); slightly polluted day $\left(35 \mu \mathrm{g} \mathrm{m}^{-3}<\mathrm{PM}_{2.5}\right.$ concentration $\leq 115 \mu \mathrm{g} \mathrm{m}^{-3}$, when IAQI of $\mathrm{PM}_{2.5}$ ranged from 50 to 150 ); and polluted day $\left(115 \mu \mathrm{g} \mathrm{m}^{-3}<\mathrm{PM}_{2.5}\right.$ concentration $\leq 350 \mu \mathrm{g} \mathrm{m}^{-3}$, when IAQI of $\mathrm{PM}_{2.5}$ ranged from 150 to 400). These pollution classes are usually based on $\mathrm{PM}_{2.5}$ concentrations averaged from 00:00 to 23:59 LT on a specific date. For our filter samples, however, the collection time extended over 2 days; nevertheless, we applied the same categorization for our measurements from 20:30 (day 1) to 20:30 LT (day 2).

\section{Optical data analysis method}

\subsection{Retrieval of aerosol complex refractive index}

The scattering and extinction coefficients of particles are calculated based on (Pettersson et al., 2004):

$\alpha_{\mathrm{ep}, \mathrm{sp}}=\int N\left(D_{\mathrm{p}}\right) \frac{\pi}{4} D_{\mathrm{p}}^{2} Q_{\text {ext,scat }}(m, x) \mathrm{d} D_{\mathrm{p}}$,

where $x=\pi D_{\mathrm{p}} / \lambda$ is the size parameter, $m=n+i k$ is the CRI of the particle (where $n$ and $k$ correspond to the real and imaginary parts of the CRI, respectively), $N$ is the number of particles per unit volume in the size bin $\mathrm{d} D_{\mathrm{p}}$ with mean diameter $D_{\mathrm{p}}$, and $\frac{\pi}{4} D_{\mathrm{p}}^{2} Q_{\text {ext,scat }}(m, x)$ is the extinction or scattering cross section $\sigma_{\text {ep,sp. }}$. The extinction or scattering efficiency, $Q_{\text {ext,scat }}$, is a function of the CRI, the morphology of the particles, and the size parameter. For chemically homogeneous spherical particles, $Q$ can be calculated from Mie theory.

The effective CRI is an effective property that averages over the aerosols' size, shape, mixing state, and chemical composition. Simultaneous measurement of the scattering and extinction coefficients by the cavity-enhanced albedometer provides a new approach for faster retrieval of the particulate CRI (Abo Riziq et al., 2007; Mack et al., 2010; Zhao et al., 2014a; Xu et al., 2016). Details of the CRI retrieval have been given in previous studies (Abo Riziq et al., 2007; Mack et al., 2010). The measured extinction and scattering coefficients $\left(\alpha_{\mathrm{ep}, 470}\right.$ and $\left.\alpha_{\mathrm{sp}, 470}\right)$ and the particle number size distribution, $N\left(D_{\mathrm{p}}\right)$, were used to determine the effective CRI on the assumption that particles were spherical and that the black carbon (BC) aerosol can be treated in a volume mixing approach. The real and imaginary parts of the effective CRI were varied (between 1.3 and 1.7 for the real part and between 0 and 0.1 for the imaginary part) to calculate the extinction and scattering coefficients for each size distribution. 
A set of refractive indices were determined by finding the minimum of the "merit function", $\chi^{2}$ (Mack et al., 2010):

$\chi^{2}=\frac{\left(\alpha_{\text {ep }}-\alpha_{\text {ep_calc }}\right)^{2}}{\varepsilon_{\alpha_{\mathrm{ep}}}^{2}}+\frac{\left(\alpha_{\mathrm{sp}}-\alpha_{\text {sp_calc }}\right)^{2}}{\varepsilon_{\alpha_{\mathrm{sp}}}^{2}}$.

Here, $\alpha_{\mathrm{ep}}$ and $\alpha_{\mathrm{sp}}$ are the measured values of the extinction and scattering coefficients, while $\alpha_{\mathrm{ep} \_}$calc and $\alpha_{\mathrm{sp} \_ \text {calc }}$ are the corresponding calculated values. $\varepsilon_{\alpha_{\mathrm{ep}}}$ and $\varepsilon_{\alpha_{\mathrm{sp}}}$ are the measurement uncertainty of $\alpha_{\mathrm{ep}}$ and $\alpha_{\mathrm{sp}}$, respectively. The mean standard deviations of the extinction and scattering coefficients over 3 min were taken as the measurement uncertainty for calculating $\chi^{2}$.

A contour plot of $\chi^{2}$ versus $n$ and $k$ was used to estimate the standard errors of $n$ and $k$. The values of $n$ and $k$ that satisfied $\chi^{2}<\chi_{0}^{2}+2.298$, which fell within the $1 \sigma$ error bound of the best measurement (with $68 \%$ confidence level of $\chi^{2}$ distribution), were considered acceptable. Projections of the contour lines (with a contour value of 2.298) on the $n$ and $k$ plane gave the standard errors $\Delta n$ and $\Delta k$, respectively (Dinar et al., 2008; Zhao et al., 2014a).

\subsection{Mass scattering and absorption efficiencies}

MSEs and MAEs are the key parameters in climate and chemical transport models for estimating radiative forcing and apportioning chemical extinction budgets (Bates et al., 2006; Malm and Hand, 2007). MSE and MAE (both conventionally in units of $\mathrm{m}^{2} \mathrm{~g}^{-1}$ ) are defined as the ratios of the light scattering and absorption coefficients $\left(\mathrm{Mm}^{-1}\right)$ to the aerosol volume mass concentration $\left(\mu \mathrm{g} \mathrm{m}^{-3}\right)$, respectively.

$\operatorname{MSE}(\mathrm{MAE})=\frac{\alpha_{\text {scat,abs }}}{M}$

Knowledge of the MSEs and MAEs of each component of atmospheric aerosol is helpful for accurate source apportionment and for estimating radiative forcing in climate modes. The simplest method for computing MSE is by direct measurement of aerosol scattering coefficient and the mass concentration. The average MSE is estimated either by dividing the average $\alpha_{\text {scat }}$ by the average mass concentration or from the slope of a linear regression of $\alpha_{\text {scat }}$ and $M$ (Hand and Malm, 2007). The MAE is calculated similarly.

In this study, the MSEs and MAEs of $\mathrm{PM}_{1.0}$ were estimated from the slope of a linear regression of $\alpha_{\text {scat,abs }}$ and $M$ (each data point with 3 min time resolution). The $\alpha_{\text {scat,abs }}$ was directly measured with the cavity-enhanced albedometer with high time resolution, and $M$ was calculated from the average density $(\bar{\rho})$ and the volume concentrations $\left(V\left(D_{\mathrm{p}}\right)\right)$ measured with the SMPS $\left(M=\bar{\rho} \int V\left(D_{\mathrm{p}}\right) \mathrm{d} D_{\mathrm{p}}\right)$. The average density was calculated from $\bar{\rho}^{-1}=\sum_{j} \rho_{j}^{-1} X_{j}$, where $\rho_{j}$ is the density of each chemical component (see Table S1 in the Supplement) and $X_{j}$ is the mass concentration ratio of each species to the total $\mathrm{PM}_{1.0}$ concentration (reconstructed with Eq. S8) measured from filter samples with a time resolution of $12 \mathrm{~h} \mathrm{sample}{ }^{-1}$. If it is assumed that only EC contributes to aerosol absorption, the MAE of EC can be determined (Knox et al., 2009; Bond et al., 2013; Cheng et al., 2011, 2016):

$\mathrm{MAE}=\frac{\int_{t_{1}}^{t_{2}} \alpha_{\mathrm{abs}} \mathrm{d} t}{\mathrm{EC}_{\mathrm{m}} \times\left(t_{2}-t_{1}\right)}$,

where $\mathrm{EC}_{\mathrm{m}}\left(\mu \mathrm{g} \mathrm{m}^{-3}\right)$ is the measured $\mathrm{EC}$ mass concentration with the aerosol carbon analyzer, and $t_{1}$ and $t_{2}$ are the start and stop times for the collection of samples with quartz filters. In this work, the integration time was determined by the quartz filter sampling period of $12 \mathrm{~h} \mathrm{sample}{ }^{-1}$. For comparison, the MAE of freshly generated BC is $8.7 \mathrm{~m}^{2} \mathrm{~g}^{-1}$ at $\lambda=470 \mathrm{~nm}$ (based on a $7.5 \pm 1.2 \mathrm{~m}^{2} \mathrm{~g}^{-1}$ at $\lambda=550 \mathrm{~nm}$ and using the inverse wavelength dependence) (Bond et al., 2006).

\subsection{Chemical apportionment of aerosol optical properties}

Chemical apportionment of light extinction of $\mathrm{PM}_{1.0}$ was determined with a revised IMPROVE (Interagency Monitoring of Protected Visual Environments) algorithm (Pitchford et al., 2007). Although the IMPROVE algorithm is a simplified predictor of extinction, it is nevertheless a useful tool to estimate the contribution of different particle components to haze levels (Pitchford et al., 2007). In this study, the optical properties were measured at $\lambda=470 \mathrm{~nm}$. The modified IMPROVE function for dry $\mathrm{PM}_{1.0}$ extinction can be rewritten as follows (with further details in Sect. S2 in the Supplement):

$$
\begin{aligned}
& \alpha_{\text {ext, } 470 \mathrm{~nm}, \mathrm{PM}_{1.0}} \\
& \approx 2.88 \times[\text { small sulfate }]+6.29 \times[\text { largesulfate }] \\
& +3.14 \times[\text { small nitrate }]+6.68 \times[\text { large nitrate }] \\
& +3.64 \times[\text { small organic mass }] \\
& +7.93 \times[\text { large organic mass }] \\
& +10.8 \times[\text { elemental carbon }]+2.23 \times[\text { sea salt }] .
\end{aligned}
$$

The large and small parts are defined by the IMPROVE formula as (Pitchford et al., 2007; Cao et al., 2012)

$[$ Large $X]=[\operatorname{total} X]^{2} / 20$, for $[$ total $X]<20 \mu \mathrm{g} \mathrm{m}^{-3}$

$[$ Large $X]=[\operatorname{total} X]$, for $[\operatorname{total} X] \geq 20 \mu \mathrm{g} \mathrm{m}^{-3}$

$[$ Small $X]=[$ total $X]-[$ large $X]$,

where $X$ is sulfate, nitrate, or organic mass $(\mathrm{OM})$. The concentration of ammonium sulfate $\left(\left[\left(\mathrm{NH}_{4}\right)_{2} \mathrm{SO}_{4}\right]\right)$ was 1.375 times the sulfate concentration $\left(\left[\mathrm{SO}_{4}^{2-}\right]\right)$, and the ammonium nitrate $\left(\left[\mathrm{NH}_{4} \mathrm{NO}_{3}\right]\right)$ was 1.29 times the nitrate concentrations $\left(\left[\mathrm{NO}_{3}^{-}\right]\right)$. The OM concentration was estimated by multiplying the reported OC concentration by a factor 


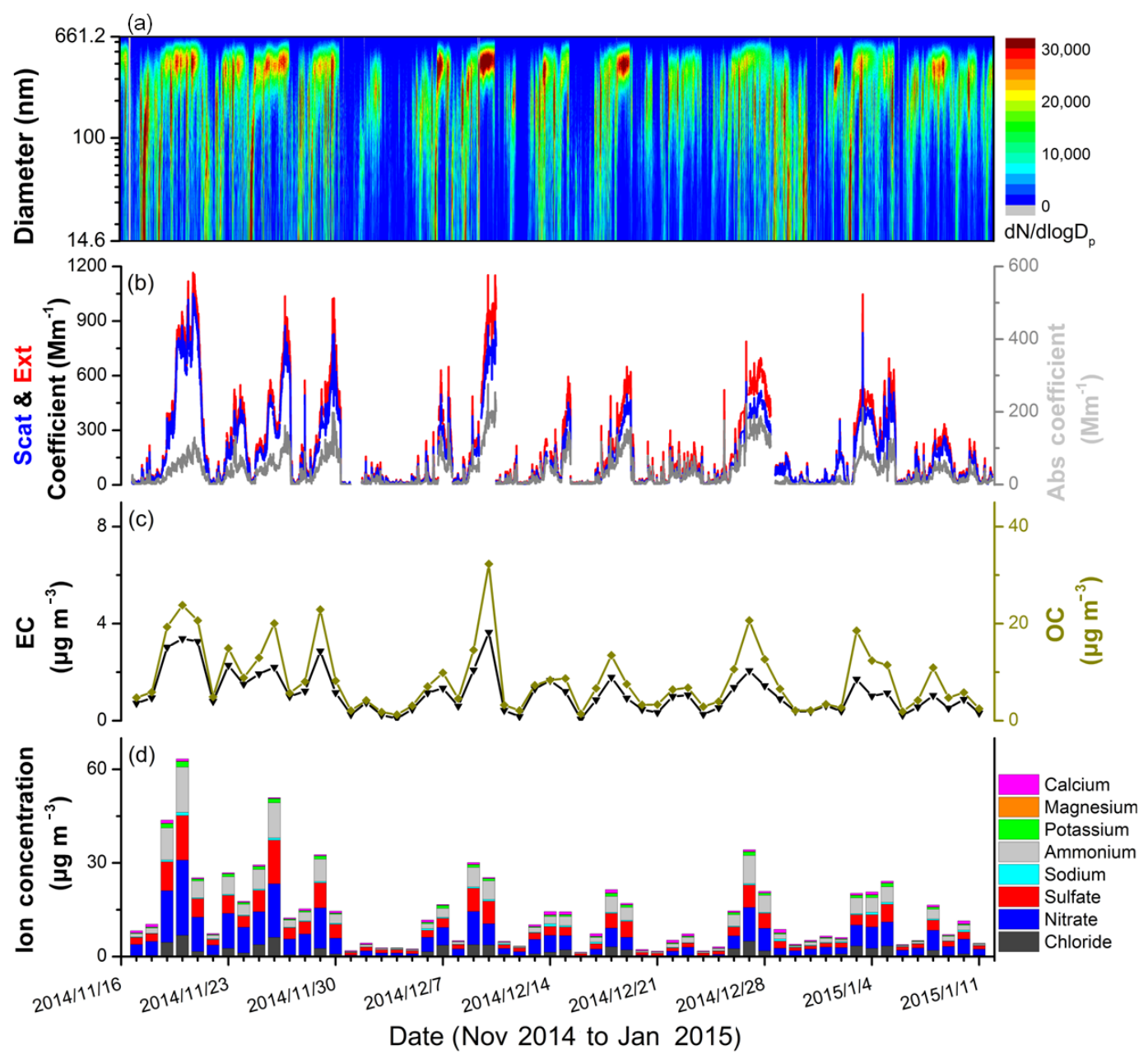

Figure 2. Time series of (a) the aerosol number size distribution measured by SMPS, (b) the extinction, scattering, and absorption coefficients at $\lambda=470 \mathrm{~nm}$ measured by cavity-enhanced albedometer, (c) organic carbon and element carbon concentration measured with an offline aerosol carbon analyzer, and (d) water-insoluble ion concentrations measured with an offline ion chromatography of dry $\mathrm{PM}_{1.0}$ particles over the sampling period.

of 1.6 (Turpin and Lim, 2001). The sea salt mass concentration was estimated by multiplying the $\mathrm{Cl}^{-}$mass concentration by a factor of 1.8 . The ammonium cation was not used directly in the IMPROVE algorithm. It was assumed to be fully neutralized by $\mathrm{SO}_{4}^{2-}$ and $\mathrm{NO}_{3}^{-}$and treated as ammonium sulfate $\left(\left(\mathrm{NH}_{4}\right)_{2} \mathrm{SO}_{4}\right)$ and ammonium nitrate $\left(\mathrm{NH}_{4} \mathrm{NO}_{3}\right)$, respectively.

\section{Results and discussion}

An overview of the measurement results of the aerosol optical properties, size distribution, and chemical composition of $\mathrm{PM}_{1.0}$ particles is shown in Table 1 and Fig. 2. There are obvious differences of the campaign average number and surface size distribution of $\mathrm{PM}_{1.0}$ for the three different pollution categories (Fig. 3). For clear days, the mean particle number size distributions fitted by a mono-log normal func- tion was around $41 \mathrm{~nm}$. Bimodal distributions were observed on slightly polluted and polluted days with modes centered at 38 and $105 \mathrm{~nm}$ (slightly polluted periods) and at 38 and $151 \mathrm{~nm}$ (polluted periods). The mode of the number size distributions exhibits the expected displacement toward the accumulation mode with increasing levels of particulate matter.

During the campaign, the measured aerosol extinction $\left(\alpha_{\mathrm{ep}, 470}\right)$, scattering $\left(\alpha_{\mathrm{sp}, 470}\right)$, and absorption coefficient $\left(\alpha_{\mathrm{ap}, 470}\right)$ ranged from 0.6 to $1165,0.1$ to 1150 , and 0 to $276 \mathrm{Mm}^{-1}$, respectively. There was no obvious correlation between extensive optical properties and wind direction (Fig. S4). With increasing pollutant level, the extensive optical properties $\left(\alpha_{\mathrm{ep}, 470}, \alpha_{\mathrm{sp}, 470}\right.$, and $\left.\alpha_{\mathrm{ap}, 470}\right)$ increased strongly, in accordance with the expected, strong dependence of particle size on light scattering. In contrast, changes in the intensive optical property, $\omega_{470}$, were more modest. The optical measurement data are presented as histograms of the 
Table 1. List of the mean optical values (aerosol extinction, scattering, absorption coefficients, and SSA at $\lambda=470 \mathrm{~nm}$ ), the effective mode diameters (particle number, surface area and volume, fitted values from the measured submicron size distribution with mono-lognormal distribution function), and chemical composition of $\mathrm{PM}_{1.0}$ particles observed in this campaign. These parameters were classified into three different pollution levels (clear, slightly polluted, and polluted days).

\begin{tabular}{|c|c|c|c|c|c|}
\hline \multicolumn{2}{|c|}{ Parameter } & \multirow{2}{*}{$\begin{array}{l}\text { Clear } \\
58.6 \pm 81.6\end{array}$} & \multirow{3}{*}{$\begin{array}{l}\begin{array}{l}\text { Slightly } \\
\text { polluted }\end{array} \\
186.7 \pm 161.6 \\
148.9 \pm 131.9\end{array}$} & \multirow{3}{*}{$\begin{array}{l}\text { Polluted } \\
567.9 \pm 292.3 \\
477.2 \pm 255.5\end{array}$} & \multirow{2}{*}{$\begin{array}{l}\text { All days } \\
200.9 \pm 239.6\end{array}$} \\
\hline \multirow{4}{*}{ Optical } & $\alpha_{\mathrm{ep}, 470}\left(\mathrm{Mm}^{-1}\right)$ & & & & \\
\hline & $\alpha_{\mathrm{sp}, 470}\left(\mathrm{Mm}^{-1}\right)$ & $47.2 \pm 64.7$ & & & $163.9 \pm 201.7$ \\
\hline & $\alpha_{\mathrm{ap}, 470}\left(\mathrm{Mm}^{-1}\right)$ & $11.6 \pm 18.3$ & $37.8 \pm 32.3$ & $90.9 \pm 55.8$ & $37.0 \pm 43.2$ \\
\hline & $\omega_{470}$ & $0.81 \pm 0.10$ & $0.79 \pm 0.07$ & $0.84 \pm 0.06$ & $0.80 \pm 0.08$ \\
\hline \multirow{3}{*}{ Size } & $D_{\mathrm{p}, \mathrm{n}}(\mathrm{nm})$ & $38 \pm 31$ & $73 \pm 51$ & $120 \pm 64$ & $67 \pm 55$ \\
\hline & $D_{\mathrm{p}, \mathrm{s}}(\mathrm{nm})$ & $374 \pm 130$ & $338 \pm 114$ & $335 \pm 76$ & $351 \pm 116$ \\
\hline & $D_{\mathrm{p}, \mathrm{v}}(\mathrm{nm})$ & $478 \pm 94$ & $480 \pm 90$ & $455 \pm 82$ & $475 \pm 91$ \\
\hline \multirow{10}{*}{$\begin{array}{l}\text { Chemical } \\
\text { composition } \\
\left(\mu \mathrm{g} \mathrm{m}^{-3}\right)\end{array}$} & $\mathrm{OC}$ & $3.41 \pm 2.43$ & $8.81 \pm 4.64$ & $20.47 \pm 6.93$ & $8.34 \pm 6.97$ \\
\hline & $\mathrm{EC}$ & $0.48 \pm 0.39$ & $1.18 \pm 0.59$ & $2.72 \pm 0.87$ & $1.12 \pm 0.92$ \\
\hline & $\mathrm{NO}_{3}^{-}$ & $1.78 \pm 1.70$ & $5.12 \pm 3.56$ & $14.99 \pm 6.54$ & $5.19 \pm 5.52$ \\
\hline & $\mathrm{SO}_{4}^{2-}$ & $1.29 \pm 0.69$ & $3.20 \pm 2.25$ & $9.62 \pm 4.55$ & $3.35 \pm 3.52$ \\
\hline & $\mathrm{NH}_{4}^{+}$ & $0.72 \pm 0.75$ & $2.98 \pm 2.32$ & $9.31 \pm 4.33$ & $2.98 \pm 3.57$ \\
\hline & $\mathrm{Cl}^{-}$ & $0.52 \pm 0.96$ & $1.48 \pm 1.41$ & $4.46 \pm 2.26$ & $1.52 \pm 1.88$ \\
\hline & $\mathrm{Ca}^{2+}$ & $0.31 \pm 0.27$ & $0.62 \pm 0.38$ & $0.58 \pm 0.33$ & $0.49 \pm 0.36$ \\
\hline & $\mathrm{K}^{+}$ & $0.16 \pm 0.25$ & $0.50 \pm 0.38$ & $1.18 \pm 0.46$ & $0.46 \pm 0.48$ \\
\hline & $\mathrm{Na}^{+}$ & $0.19 \pm 0.22$ & $0.33 \pm 0.28$ & $0.60 \pm 0.38$ & $0.32 \pm 0.30$ \\
\hline & $\mathrm{Mg}^{2+}$ & $0.04 \pm 0.03$ & $0.08 \pm 0.03$ & $0.09 \pm 0.03$ & $0.06 \pm 0.04$ \\
\hline
\end{tabular}

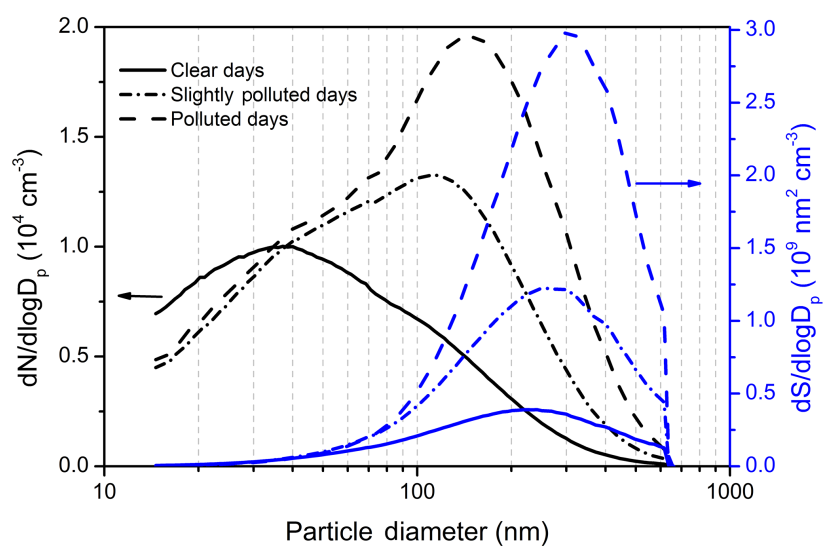

Figure 3. The mean number and surface size distribution of ambient aerosol on clear, slightly polluted, and polluted days.

relative frequency of occurrence of $\alpha_{\mathrm{ep}, 470}, \alpha_{\mathrm{sp}, 470}, \alpha_{\mathrm{ap}, 470}$, and $\omega_{470}$ (Fig. S5) and diurnal variations of hourly averaged extinction, scattering, absorption coefficients, and SSA on clear, slightly polluted, and polluted days are presented in Fig. S6. Diurnal variations of the optical properties were broadly similar for different pollutant levels but tended to be more marked under clean conditions and modest under polluted conditions. The Huairou site is a new suburban site at which aerosol optical properties have not previously been reported. To put our observations at Huairou in context, the scattering and absorption coefficients and SSA observed in this campaign are also compared (in Sect. S5) to those at a selection of other locations (urban, suburban, and rural sites).

We present our results as follows: firstly, selected periods are investigated in detail for showing the process of haze formation, development and decline. The extensive optical properties (extinction, scattering, and absorption coefficients) and intensive optical properties (SSA and effective CRI) are presented for these periods. Secondly, the mass scattering and absorption efficiencies are determined. And finally, the chemical composition on different pollution days during the campaign are considered. Chemical apportionment of aerosol extinction is then studied based on the modified IMPROVE algorithm.

\subsection{Temporal variations of optical properties during selected air pollution episodes}

The temporal variations of aerosol particle number and surface size distribution, aerosol extinction, scattering, absorption coefficients, $\omega_{470}$, and the retrieved effective CRIs from 22 to 24 November 2014 are presented in Fig. 4. The corresponding temporal wind direction and speed are shown in the upper panel of Fig. 4, while temperature, relative humidity, pressure, and concentrations of pollutant gases $\left(\mathrm{SO}_{2}\right.$, $\mathrm{NO}_{2}, \mathrm{O}_{3}$, and $\mathrm{CO}$ ) are shown in Fig. S7. The time series of $\mathrm{PM}_{1.0}$ particle number distribution during the episode varied with meteorology and the sources of pollutants. To empha- 


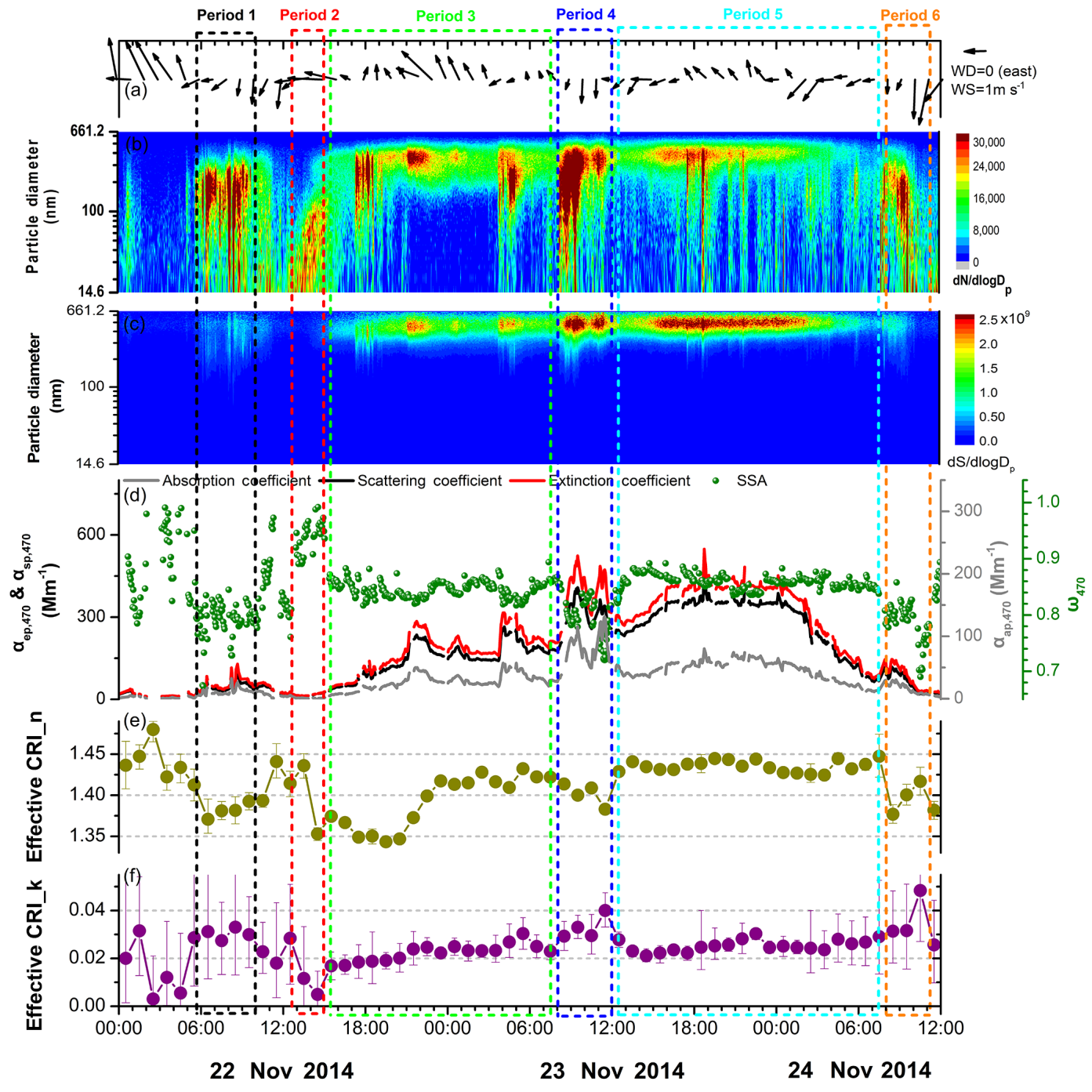

Figure 4. Highly time-resolved evolution of a selected air pollution episode during 22-24 November 2014. (a) Particle number size distribution; (b) particle surface size distribution; (c) aerosol extinction, scattering, absorption coefficients, and SSA at $\lambda=470 \mathrm{~nm}$; (d) retrieved real part of CRI; (e) retrieved imaginary part of CRI. The air pollution episode was divided into six shorter periods to clearly show the evaluation of optical properties during haze formation, development, and decline.

size the variation of these parameters during the episode, the extended air pollution episode was divided into six shorter periods. The statistical analyses of these periods are summarized in Table 2. In the selected haze episode, these six periods show variations in the $\mathrm{PM}_{1.0}$ size distribution and the extensive optical properties of particles in the process of haze formation, development, and decline. The evolution of intensive optical properties was related to the variation of $\mathrm{PM}_{1.0}$ chemical components.

Twenty-four hour back trajectories starting at $200 \mathrm{~m}$ a.g.l. in Huairou site calculated every $4 \mathrm{~h}$ (at $02: 00$, 6:00, 10:00, 14:00, 18:00, and 22:00 LT) are shown in Fig. 5 (http://ready.arl.noaa.gov/HYSPLIT.php). The trajectories from the northerly direction were clean air masses with high transport heights and long transport pathways; trajectories from the southerly direction were mainly polluted air masses with low transport heights and short transport pathways.

During Period 1 and Period 6, winds were typically from the northeast; the trajectory indicated that the air masses came from cleaner air to the north and carried pollutants from northeastern areas to the observation site, with concentrations of small, light absorption particles increasing. These clean air masses showed a relatively large contribution from traffic emissions. Lower values of the SSA were found during the rush hour, in common with other studies that have similarly found minimum SSA values during the morning traffic rush hour (Garland et al., 2008; Lyamani et al., 2010).

For Period 2, the air masses came from the north with clean air, but their reduced height resulted in entrainment of surface aerosols and transport to the observation site. The 
Table 2. List of aerosol mean diameters and optical properties during the selected haze episode.

\begin{tabular}{llllllllll}
\hline Episode & Date (LT) & $\begin{array}{l}\text { Number } \\
\text { mean } \\
\text { diameter } \\
(\mathrm{nm})\end{array}$ & $\begin{array}{c}\text { Surface } \\
\text { mean } \\
\text { diameter } \\
(\mathrm{nm})\end{array}$ & $\begin{array}{l}\alpha_{\mathrm{ep}, 470} \\
\left(\mathrm{Mm}^{-1}\right)\end{array}$ & $\begin{array}{l}\alpha_{\mathrm{sp}, 470} \\
\left(\mathrm{Mm}^{-1}\right)\end{array}$ & $\begin{array}{l}\alpha_{\mathrm{ap}, 470} \\
\left(\mathrm{Mm}^{-1}\right)\end{array}$ & $\begin{array}{c}\omega_{470} \\
\end{array}$ & $\begin{array}{l}\text { Real part of } \\
\text { effective } \\
\text { CRI }(n)\end{array}$ & $\begin{array}{l}\text { Imaginary part } \\
\text { of effective } \\
\text { CRI }(k)\end{array}$ \\
\hline Period 1 & 22 Nov 05:40-10:00 & $56 \pm 6$ & $193 \pm 19$ & $56 \pm 24$ & $44 \pm 19$ & $12 \pm 6$ & $0.79 \pm 0.03$ & $1.38 \pm 0.06$ & $0.03 \pm 0.02$ \\
Period 2 & 22 Nov 12:40-15:00 & $25 \pm 4$ & $193 \pm 17$ & $17 \pm 5$ & $16 \pm 5$ & $1.0 \pm 0.4$ & $0.94 \pm 0.03$ & $1.40 \pm 0.06$ & $0.008 \pm 0.005$ \\
Period 3 & 22 Nov 15:30-23 Nov 08:00 & $106 \pm 16$ & $229 \pm 16$ & $179 \pm 69$ & $151 \pm 57$ & $28 \pm 12$ & $0.85 \pm 0.01$ & $1.39 \pm 0.04$ & $0.02 \pm 0.006$ \\
Period 4 & 23 Nov 08:30-12:00 & $105 \pm 16$ & $251 \pm 15$ & $405 \pm 60$ & $321 \pm 42$ & $84 \pm 22$ & $0.79 \pm 0.03$ & $1.40 \pm 0.03$ & $0.034 \pm 0.008$ \\
Period 5 & 23 Nov 12:30-24 Nov 07:30 & $124 \pm 19$ & $263 \pm 11$ & $330 \pm 110$ & $283 \pm 94$ & $46 \pm 16$ & $0.86 \pm 0.01$ & $1.44 \pm 0.03$ & $0.02 \pm 0.01$ \\
Period 6 & 24 Nov 08:00-11:10 & $80 \pm 42$ & $226 \pm 14$ & $80 \pm 42$ & $64 \pm 34$ & $16 \pm 8$ & $0.78 \pm 0.04$ & $1.40 \pm 0.04$ & $0.04 \pm 0.02$ \\
\hline
\end{tabular}
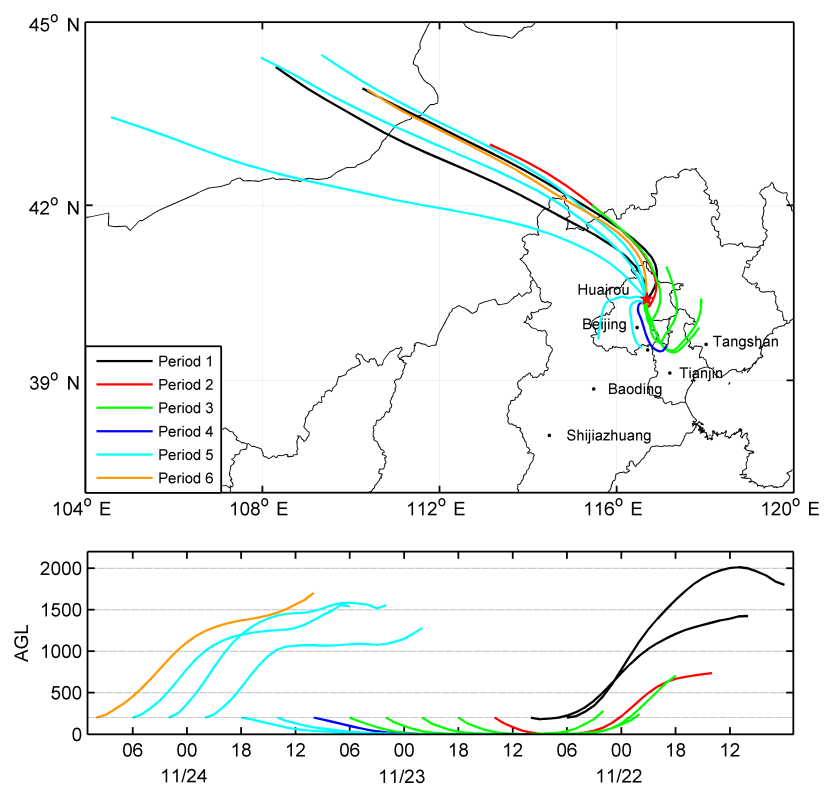

Figure 5. The $24 \mathrm{~h}$ back trajectories starting at $200 \mathrm{~m}$ above ground level in Huairou site were calculated every $4 \mathrm{~h}$ (at 00:00, 06:00, 12:00, and 18:00 local time) during the selected air pollution episode.

transport of clean, fresh air resulted in sharply decreased pollutant levels and promoted new particle formation. Takegawa et al. (2009) and Guo et al. (2014) showed that newly formed Aitken mode particles were mainly composed of sulfate and organic matter, indicating that most components were absolute scattering species. In this case, the values of SSA and $k$ should be close to 1 and 0 , respectively. The retrieved values of SSA $(0.94 \pm 0.03)$ and $k(0.008 \pm 0.005)$ matched these expectations and indicate that the newly formed particles were predominantly scattering species.

For Periods 3 and 4, the shorter transport pathway of air masses suggested that the composition was dominated by local emissions, including primary emissions and secondary formation. Period 3 was characterized by the dominance of larger accumulation mode particles for several hours. In the first part of the period, the winds slowed down and turned to the south. These conditions favored accumulation of local pollutants (including primary emissions and secondary production) and transportation of pollutants from southern areas. Later on, the wind speed increased and the direction changed to the southeast. The accumulation of pollutants brought about the formation of haze.

Large numbers of small, light absorbing particles were seen during Period 4, which coincided with the morning rush hour. The mean values of $\omega_{470}$ and effective CRI were similar to the values in Period 1 within the observed variability. During the period, weak winds from northern directions transported polluted air to the observation site and resulted in higher concentrations and a greater influence of light absorbing particles. The accumulation of original and newly discharged primary pollutants led to sharp variations in the aerosol size distribution and extensive optical properties. However, variations in the aerosol intensive optical properties were slight.

High extinction values were observed over Period 5, with a gradual increase and then decrease in extinction, scattering, and absorption. The mean values of $\omega_{470}, n$ and $k$ were $0.86 \pm 0.01,1.44 \pm 0.03$, and $0.02 \pm 0.01$, respectively. The SSA values were larger than those reported for Period 4. In general, the $n$ values were higher and the $k$ values lower than those seen in Period 4, although the mean values of both properties fall within the combined standard deviations of both periods. For this period, the airflow passed over the Beijing city area and over the southwestern direction of the observation site, bringing surface air pollutants to the Huairou site and contributing to the formation of serious haze. Both the mean diameter of the number and surface size distribution $(124 \pm 19$ and $263 \pm 11 \mathrm{~nm})$ and $n$ were larger in this period than in the other five periods. The light scattering efficiency increased with the increment of the particle size.

According to the regulatory classification of the atmospheric pollution level, these six periods can be divided into two categories: clear day (22:00 LT 21 November-10:00 LT 22 November) and polluted day (10:00 LT 22 November22:00 LT 22 November, 22:00 LT 22 November-10:00 LT 23 November, 10:00 LT 23 November-22:00 LT 23 November, 22:00 LT 23 November-10:00 LT 24 November). The mean value of the total mass concentration on clear days 

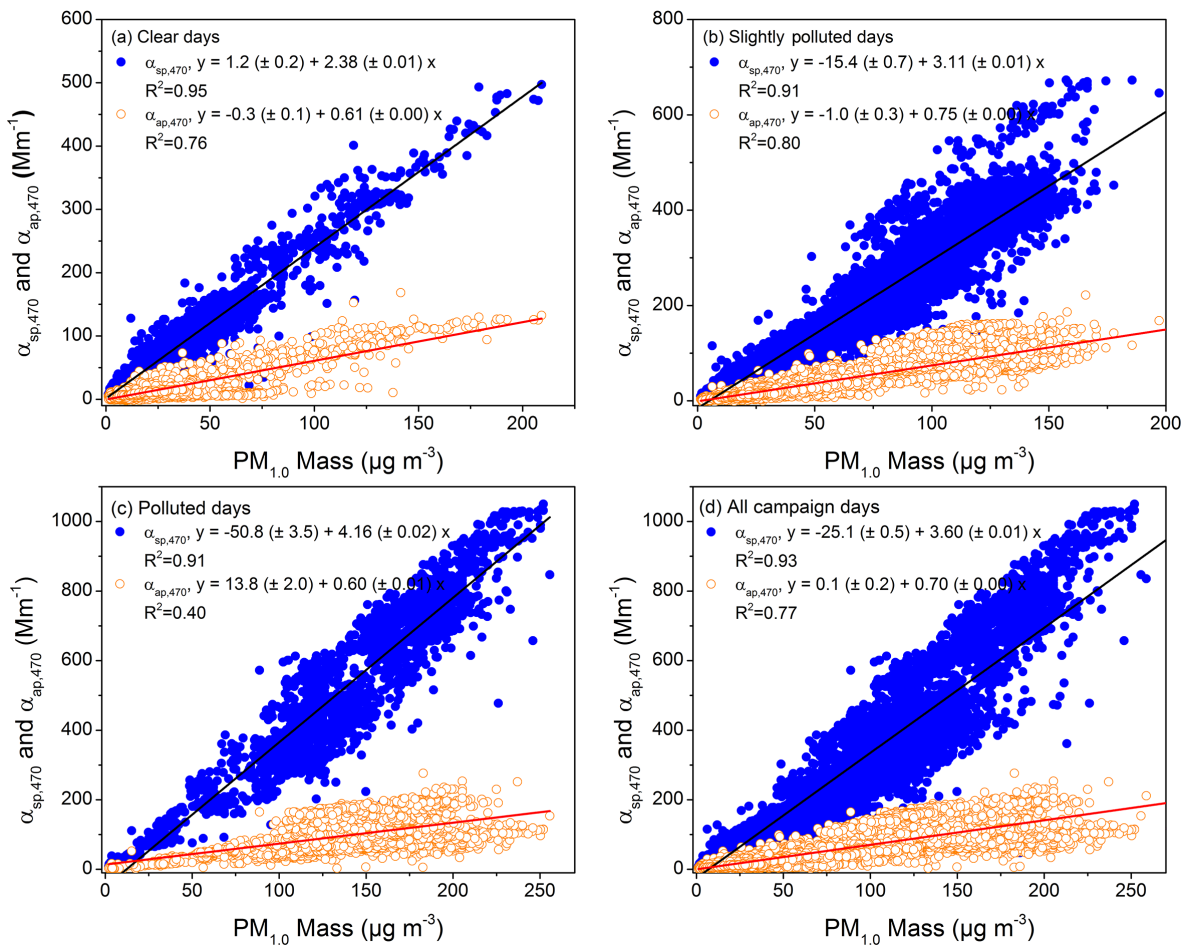

Figure 6. Scatter plots of the measured scattering and absorption coefficients at $\lambda=470 \mathrm{~nm}$ against $\mathrm{PM}_{1.0}$ mass concentrations for $\mathrm{PM}_{1.0}$ particles under different pollution level.

was $9.49 \mu \mathrm{g} \mathrm{m}^{-3}$, and the mean fractional contributions of $\mathrm{OM}$, nitrate, and sulfate were $56 \%\left(5.32 \mu \mathrm{g} \mathrm{m}^{-3}\right), 12 \%$ $\left(1.12 \mu \mathrm{g} \mathrm{m}^{-3}\right)$, and $14 \%\left(1.34 \mu \mathrm{g} \mathrm{m}^{-3}\right)$, respectively. On polluted days, the mean value of the total mass concentration was $41.6 \mu \mathrm{g} \mathrm{m}^{-3}$ with fractional contributions of $44 \% \mathrm{OM}$ $\left(18.5 \mu \mathrm{g} \mathrm{m}^{-3}\right), 22 \%$ nitrate $\left(9.3 \mu \mathrm{g} \mathrm{m}^{-3}\right)$, and $11 \%$ sulfate $\left(4.5 \mu \mathrm{g} \mathrm{m}^{-3}\right)$. In summary, in going from clear to polluted days, the fractional contribution of OM to the total mass decreased by $12 \%$, whereas the fraction of nitrate almost doubled and that of sulfate decreased slightly. Organic matter was the largest contributor to $\mathrm{PM}_{1.0}$. The notable increase in the concentration and fractional contribution to $\mathrm{PM}_{1.0}$ extinction coefficient of inorganic species, and specifically nitrate and ammonium, indicates that the inorganic contribution to particulate matter becomes relatively more important than the $\mathrm{OM}$ fraction during haze. The chemical composition is discussed further in Sect. 4.3.

\subsection{Mass scattering and mass absorption efficiencies}

\subsubsection{MSE and MAE of $\mathrm{PM}_{1.0}$}

Figure 6 shows the relationship between the scattering and absorption coefficients and $\mathrm{PM}_{1.0}$ mass concentrations under different pollution levels. The $\mathrm{PM}_{1.0}$ mass concentrations were determined by multiplying the volume concentrations with the volume-weighted mass density of each filter sample (Hasan and Dzubay, 1983). The scattering and (to a lesser extent) the absorption coefficients were generally well correlated with the $\mathrm{PM}_{1.0}$ mass concentrations and have small $y$ intercepts. (The larger deviation of the $y$ intercept on polluted days likely stems from the smaller number of low mass concentration observations on these days.)

The derived $\mathrm{PM}_{1.0}$ average mass scattering and absorption efficiencies during the campaign were 3.60 and $0.70 \mathrm{~m}^{2} \mathrm{~g}^{-1}$, respectively (Fig. 6d). Statistical uncertainties from the slope of the regression are misleadingly small and have been omitted in the reported MSE and MAE values. The MSE and MAE values are smaller than those observed by Garland et al. (2008) from suburban Guangzhou in July 2006 (where the $\mathrm{PM}_{1.0}$ mass scattering and absorption efficiency calculated assuming an average effective density of ammonium sulfate $\left(1.7 \mathrm{~g} \mathrm{~cm}^{-3}\right)$ were 4.13 and $1.09 \mathrm{~m}^{2} \mathrm{~g}^{-1}$, respectively), the value of $\mathrm{PM}_{2.5}$ at $\lambda=520 \mathrm{~nm}$ obtained in urban Beijing $\left(4.8 \mathrm{~m}^{2} \mathrm{~g}^{-1}\right)$ during wintertime (Tao et al., 2015), and in Chengdu and Guangzhou $\left(3.9 \mathrm{~m}^{2} \mathrm{~g}^{-1}\right)$ (Tao et al., $2014 a, b)$. The derived mass extinction efficiency (MEE) is $4.30 \mathrm{~m}^{2} \mathrm{~g}^{-1}$, which was comparable to the reported values during Aerosols 1999 (4.1-5.4 $\left.\mathrm{m}^{2} \mathrm{~g}^{-1}\right)$ (Quinn et al., 2001) and INDOEX 1999 (4.0-5.6 $\left.\mathrm{m}^{2} \mathrm{~g}^{-1}\right)$ (Quinn et al., 2002).

In this work, the MSE of $\mathrm{PM}_{1.0}$ was $4.16 \mathrm{~m}^{2} \mathrm{~g}^{-1}$ during polluted days, which was $34 \%$ higher than that during the slightly polluted days $\left(3.11 \mathrm{~m}^{2} \mathrm{~g}^{-1}\right)$ and $75 \%$ higher than that during the clear days $\left(2.38 \mathrm{~m}^{2} \mathrm{~g}^{-1}\right)$ (Fig. 6a-c). The variability in MSE typically depends more on the mass size 


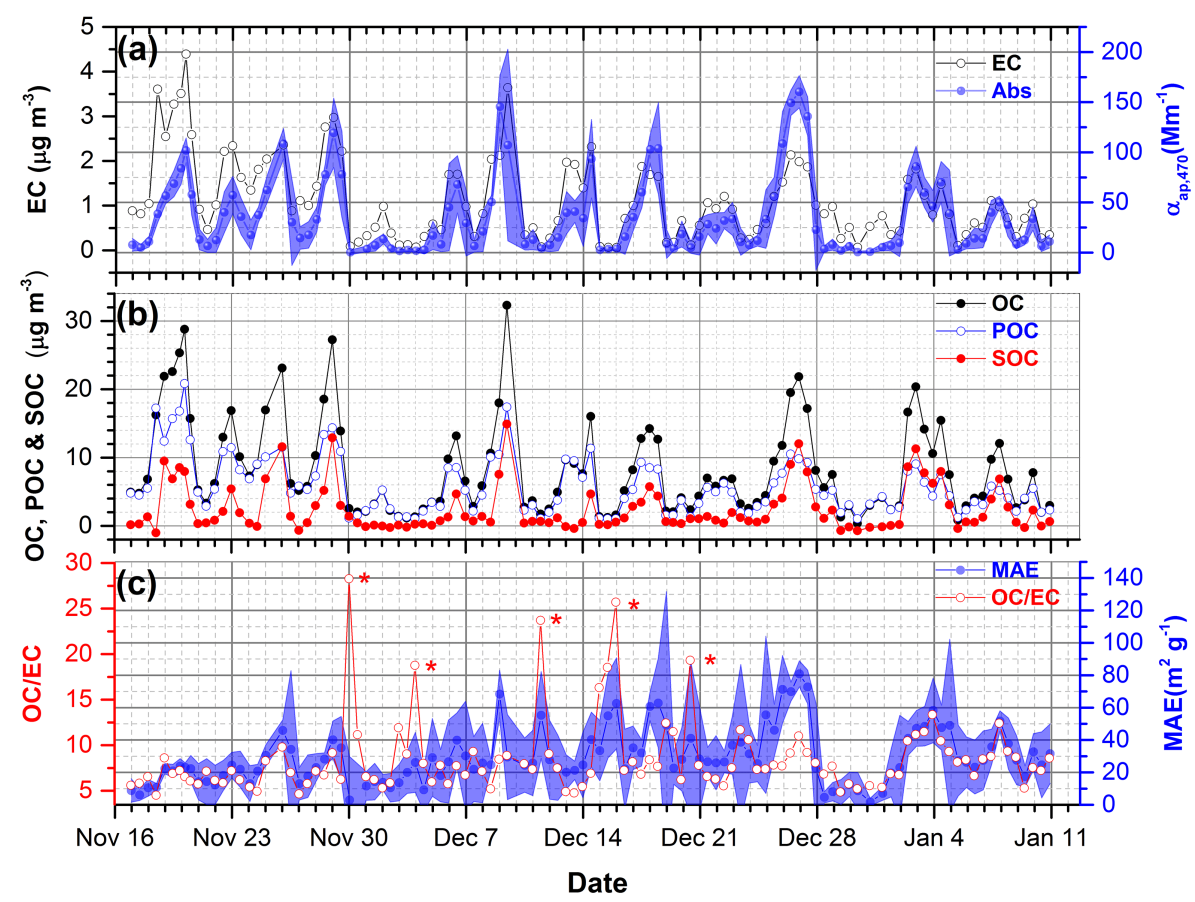

Figure 7. Time series of (a) the measured EC mass concentrations and absorption coefficients at $\lambda=470 \mathrm{~nm}$; (b) the measured OC mass concentrations and the estimated primary OC (POC) and secondary OC (SOC) mass concentrations determined with the EC-tracer method (Lim and Turpin, 2002; Lin et al., 2009; Cheng et al., 2011, the details of the calculation method are given in Sect. S7); and (c) the MAE values of EC and OC to EC ratio (OC/EC). The MAE was calculated by dividing the measured absorption coefficient by the measured concentration of EC. The blue shaded areas indicate the standard deviation. The red stars associated with unusually high values in (c) may arise from artifacts arising from sampling or handling of the filter.

distribution than on density or refractive index (Hand and Malm, 2007). As shown in Fig. 3, the particle diameter increased significantly with high aerosol mass concentrations. The MSEs in this work increased consistently with pollution level, primarily because larger particles scatter light more efficiently. Cheng et al. (2015) showed that the MSEs of ammonium nitrate, ammonium sulfate, and organic matter increased rapidly with increasing mass concentration at lower aerosol loadings, while the MSEs of ammonium nitrate and ammonium sulfate fluctuated in a narrow range under high aerosol loading conditions when the MSE of organic matter was slightly smaller. One recent study (Tao et al., 2015) showed that the MSE was determined by the proportions of the dominant chemical components and their size distributions under different pollution levels. The MSEs in this work increased consistently with the mass concentration of particles because of the relationship between size and light scattering efficiency.

\subsubsection{MAE of EC}

Similar time profiles are seen for the measured absorption coefficient at $\lambda=470 \mathrm{~nm}$ and the measured mass concentrations of EC and $\mathrm{OC}$ (Fig. 7a and b). Assuming that only EC contributes to aerosol absorption, the MAE of
EC can be calculated using Eq. (4). The MAE values of $\mathrm{EC}$ at $\lambda=470 \mathrm{~nm}$ over the campaign period are shown in Fig. $7 \mathrm{c}$. These values vary widely, with lower values generally seen under cleaner conditions and higher values observed under more polluted conditions. The MAE values for selected clear days (e.g., 17-18 November; 1-3 December; 29 December 2014-1 January 2015) ranged from 7 to $14 \mathrm{~m}^{2} \mathrm{~g}^{-1}$ (average of $10.3 \pm 2.7 \mathrm{~m}^{2} \mathrm{~g}^{-1}$ ) and are comparable to those reported in Beijing during the summer (5$13 \mathrm{~m}^{2} \mathrm{~g}^{-1}$ ) (Cheng et al., 2011). Much higher values were seen on polluted days, where the MAE ranged from 23 to $81 \mathrm{~m}^{2} \mathrm{~g}^{-1}$ (average of $48 \pm 21 \mathrm{~m}^{2} \mathrm{~g}^{-1}$ ) for the period covered 23-28 December 2014 and from 20 to $49 \mathrm{~m}^{2} \mathrm{~g}^{-1}$ (average of $42 \pm 14 \mathrm{~m}^{2} \mathrm{~g}^{-1}$ ) for 2-5 January 2015. These values are comparable to those reported by Chan et al. (2011), where MAE ranged from 10 to $50 \mathrm{~m}^{2} \mathrm{~g}^{-1}$.

The average EC mass concentrations were $0.48 \pm 0.39$, $1.18 \pm 0.59$, and $2.72 \pm 0.87 \mu \mathrm{g} \mathrm{m}^{-3}$, for clear, slightly polluted, and polluted days, respectively. The corresponding mass fractions of $4.3 \pm 3.6,4.0 \pm 2.0$, and $3.6 \pm 1.1 \%$ were approximately equal within the large variability seen on different days. The mean and standard deviations of MAE values of EC were $23.0 \pm 14.0,32.7 \pm 16.0$, and $35.0 \pm 21.7 \mathrm{~m}^{2} \mathrm{~g}^{-1}$, respectively, for clear, slightly polluted, and polluted days. Our values suggest that EC absorption 
was strongly enhanced over the campaign period. Enhanced absorption $\left(E_{\text {abs }}\right)$ could arise from the coating enhancement of ambient $\mathrm{BC}$ absorption (lensing-driven enhancement), as well as absorption associated with light-absorbing organic compounds (brown carbon, BrC) (Andreae and Gelencsér, 2006; Bond et al., 2013; Gustafsson and Ramanathan, 2016). In general, light absorption from other organic species tends to be relatively small at $\lambda=470 \mathrm{~nm}$, whether it arises from small nitroaromatic compounds (Claeys et al., 2012) or from larger HULIS-type substances (Di Lorenzo and Young, 2016).

Laboratory studies report a BC enhancement factor from 1.8 to 2 for thicker coatings (Bond et al., 2013). Results from field observations are more variable (Peng et al., 2016): reported $E_{\mathrm{abs}}$ values ranged from 1.06 (Cappa et al., 2012; Lan et al., 2013) to 1.7 (Lack et al. 2012; Liu et al., 2015), although two recent studies (Cui et al., 2016; Peng et al., 2016) have found that for aged BC (18 and $4.6 \mathrm{~h}$ after fresh emission in clear and polluted condition, respectively), $E_{\text {abs }}$ ranged from 2 to 3 . Compared to freshly emitted BC, we observe average absorption enhancements of 2.6 (clear), 3.8 (slightly polluted), and 4.0 (polluted) for different days. Our values are somewhat higher, although broadly consistent with, than Peng et al. (2016).

Our individual MAEs of EC values are often appreciably higher than has been observed in other studies (Andreae et al., 2008; Cheng et al., 2011; Wang et al., 2014). This difference may arise from either measurement uncertainties or the contribution of other absorbing species. Large MAE values could arise in part from inaccuracies in both the EC mass concentration or $\alpha_{\text {abs }}$ (which is itself determined from the relatively small difference between the extinction and scattering measurements). Moreover, our assumption that all particle absorption arises from EC would lead to higher MAE values if there were simultaneous absorption by other species. L. Wang et al. (2013) have recently shown that $\mathrm{BrC}$ was the second-largest absorbing aerosol constituent in Beijing (with a volume fraction of 5-25\% in the total aerosol volume) and exhibits a clear seasonal variation (dominates in late fall and winter, and extremely low in summer). The sources of $\mathrm{BrC}$ have been reported to be the organic components primary emitted from the combustion of biomass and fossil fuels. In a study of biomass burning particle, Lack et al. (2012) showed that the contribution of the absorption of $\mathrm{BrC}$ was about $27 \%$ at $\lambda=404 \mathrm{~nm}$, while other recent studies (Nakayama et al., 2013; Moise et al., 2015) have shown that secondary organic aerosol (SOA) may also act as $\mathrm{BrC}$.

Our data provide some support for the suggestion that SOA is absorbing. Since primary OC and EC are mostly emitted from the same source, EC is a good tracer of primary combustion-generated carbon emissions and the OC/EC ratio can be used as an indicator for the formation of SOA (Cheng et al., 2011). Time-resolved OC and EC data provide a better understanding of the dynamics of SOA formation. In this work, the pattern of MAE coincided well with OC/EC

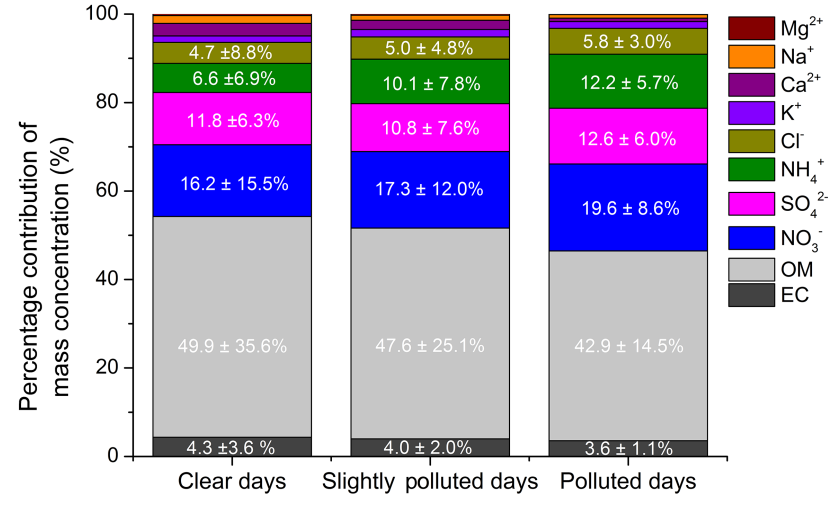

Figure 8. The percentage contribution of the mass concentrations of OM, EC concentrations and eight water-soluble ion components on clear, slightly polluted, and polluted days.

ratio, suggesting that SOA has a non-negligible absorption on polluted days. This also implies that our MAE values reported above are upper limits and that the absorption contribution of EC is likely to be somewhat smaller.

\subsection{Chemical composition and light extinction apportionment on different air pollution days}

\subsubsection{Chemical composition}

Table 1 and Fig. 8 show the mean mass concentration values and the mean percentile compositions of observed chemical compositions of $\mathrm{PM}_{1.0}$ particles under different pollution levels. The contribution of sulfate, nitrate, and ammonium to the observed $\mathrm{PM}_{1.0}$ mass concentration increased strongly on polluted compared to clear days (from 34 to $44 \%$ ). Similar trends were observed for $\mathrm{PM}_{2.5}$ and NR-PM 1.0 during the January 2013 severe haze events in Beijing (Sun et al., 2014; Tao et al., 2015; G. J. Zheng et al., 2015).

On average, OM, nitrate, sulfate, ammonium, chloride and EC comprised $46.3 \%\left(13.3 \pm 11.1 \mu \mathrm{g} \mathrm{m}^{-3}\right), 18.0 \%$ $\left(5.2 \pm 5.5 \mu \mathrm{g} \mathrm{m}^{-3}\right), \quad 11.6 \% \quad\left(3.3 \pm 3.5 \mu \mathrm{g} \mathrm{m}^{-3}\right), \quad 10.3 \%$

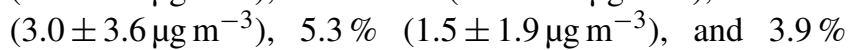
$\left(1.1 \pm 0.9 \mu \mathrm{g} \mathrm{m}^{-3}\right)$ of observed $\mathrm{PM}_{1.0}$, respectively. The organic mass was the largest proportion in $\mathrm{PM}_{1.0}$ particles, and the contribution of nitrate was larger than that of sulfate. Compared to summer, the mass contribution of organics was significantly higher during winter, and primary organic aerosol dominated during the coal heating season (Sun et al., 2013). Huang et al. (2014) reported that SOA contributed $26 \%$ of $\mathrm{PM}_{2.5}$ in Beijing in the January 2013 severe haze events and indicated the dominant effect of fossil fuel SOA formation in Beijing regions.

Compared to sulfate, the fractional composition of nitrate and ammonium aerosol increased under high levels of pollution. Similar increases in the proportion of secondary inorganic species, and particularly nitrates, have been observed 
(a) Clear days

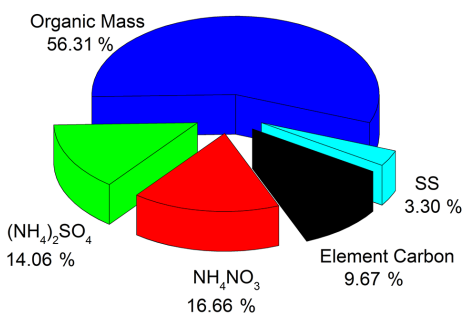

(c) Polluted days

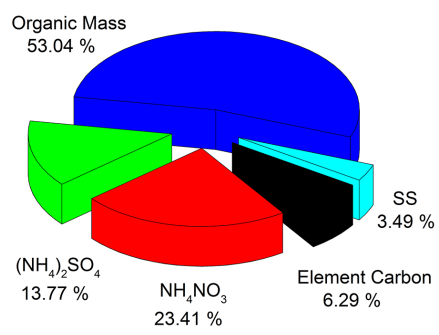

(b) Slightly polluted days

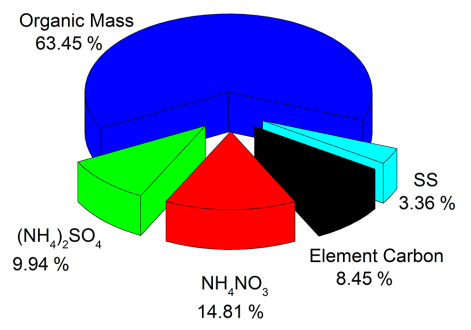

(d) All campaign days

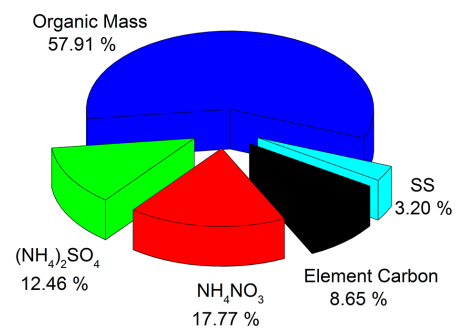

Figure 9. Average fractional contribution of each chemical composition to dry $\mathrm{PM}_{1.0}$ extinction coefficient with respect to different pollution level.

during other haze episodes in the North China Plain and other Chinese megacities (Pathak et al., 2009; Jansen et al., 2014; Tian et al., 2015). Based on the relative abundances of nitrate and ammonium, these increases have been attributed to gas phase formation of nitrate from $\mathrm{HNO}_{3}$ and $\mathrm{NH}_{3}$. In our results, the molar ratios $\left[\mathrm{NO}_{3}\right] /\left[\mathrm{SO}_{4}\right]$ and $\left[\mathrm{NH}_{4}\right] /\left[\mathrm{SO}_{4}\right]$ fall between 2.1 to 2.5 and 3.0 to 5.2 , respectively (based on the mean concentrations of these components), and they are consistent with this explanation for an ammonium-rich regime (Pathak et al., 2009; Tian et al., 2015). It is worth noting that the increases in secondary inorganic species are not universal: some studies have reported haze episodes (or portions of such episodes) in which the organic fraction increases substantially (Tian et al., 2015; Wang et al., 2015). This difference likely reflects the relative importance of sources and atmospheric processing in both the gas and liquid phases during such events (Tian et al., 2016).

\subsubsection{Chemical apportionment of aerosol optical properties}

Over the past years, the chemical apportionment of $\alpha_{\text {ep }}$ or $\alpha_{\text {sp }}$ has been conducted in both urban and non-urban regions (Malm et al., 1994; Watson, 2002; Cheung et al., 2005; Malm and Hand, 2007; Yang et al., 2007; Tao et al., 2009; Cao et al., 2012; Han et al., 2014; Tao et al., 2014a; Cheng et al., 2015). Ammonium sulfate was generally the largest contributor to $\mathrm{PM}_{2.5}$ or $\mathrm{PM}_{10} \alpha_{\mathrm{ep}}$, with a range from 20 to $50 \%$. However, fewer studies have been reported of the chemical contribution of different chemical components to the extinction of $\mathrm{PM}_{1.0}$ under different pollution levels.
In this work, the average fractional contributions of each chemical component of dry $\mathrm{PM}_{1.0}$ extinction coefficient with respect to different pollution levels were calculated with the IMPROVE algorithm (Fig. 9). The optical extinction of OM, ammonium nitrate, ammonium sulfate, elemental carbon, and sea salt accounted for 57.9, 17.8, 12.5, 8.6, and 3.2\% of the reconstructed $\mathrm{PM}_{1.0}$ extinction in this campaign, respectively. The contribution of chemical compositions to aerosol extinction depends mainly on their mass concentrations. OM, ammonium nitrate, ammonium sulfate, element carbon, and sea salt accounted for 50.4, 21.2, 16.8, 4.2, and $7.4 \%$ of the reconstructed $\mathrm{PM}_{1.0}$ mass concentrations, respectively. The organic constituents comprised a large fraction of $\mathrm{PM}_{1.0}$ mass concentration, consistent with previous studies (Yao et al., 2010; Sun et al., 2013) and, therefore, made the largest contribution to the extinction of $\mathrm{PM}_{1.0}$ particles in this study. The relative contribution of OM $(58 \%)$ to the total extinction reported here was comparable to that previously reported in Beijing (54\%) during an extreme haze episode in January 2013 for $\mathrm{PM}_{1.0}$ scattering (Wang et al., 2015) and in Shenzhen (45\%) in the winter of 2009 for $\mathrm{PM}_{2.5}$ extinction (Yao et al., 2010). The contribution of organics in Beijing increases during the winter coal heating season (Sun et al., 2013). Emissions from the large number of vehicles in the megacities of China also contribute significantly to organic aerosol (Huang et al., 2014). From clear days to slightly polluted days, the relative contribution of organic mass to light extinction increased by $7 \%$, which may due to an increasing contribution of SOA (Huang et al., 2014). The concentrations of nitrate and ammonium aerosol increased under high levels of pollution, and the relative contribution of ammonium ni- 
trate to $\mathrm{PM}_{1.0}$ light extinction increased by $6.7 \%$ under these conditions (Wang et al., 2015).

The parameterization of EC extinction in the modified IMPROVE algorithm is based on the optical properties of freshly emitted EC. However, Sect. 4.2 showed that, both in our work and in previous studies, EC absorption in ambient aerosols is enhanced several fold. Not accounting for the effective absorption of EC will underestimate the extinction, as in indeed borne out in the correlation between calculated and measured extinctions (Fig. S3c). To address this issue, we investigated parameterizing the IMPROVE algorithm based on the absorption enhancement of 2.4 fold recently reported by Peng et al. (2016). The BC term in the modified IMPROVE function was changed as follows: (1) an absorption enhancement factor of 2.4 gave a new MAE value of $20.9 \mathrm{~m}^{2} \mathrm{~g}^{-1}$ for $\mathrm{BC}$ at $\lambda=470 \mathrm{~nm}$ and (2) a scattering contribution from EC (based on an SSA of 0.2; Bond et al., 2006) produced a MSE value of $2.18 \mathrm{~m}^{2} \mathrm{~g}^{-1}$ for BC. The MEE term $\left(10.8 \mathrm{~m}^{2} \mathrm{~g}^{-1}\right)$ in the modified IMPROVE was replaced with the summation of the two parts $\left(23 \mathrm{~m}^{2} \mathrm{~g}^{-1}\right.$ at $\left.\lambda=470 \mathrm{~nm}\right)$. These changes raised the calculated aerosol extinction by $8 \%$ (Fig. S10), thereby improving the agreement with measurements. The deviation of the correlation between calculations and measurements from unity was reduced from 23 to $15 \%$. The revised MEE of EC doubled the contribution of EC to the total aerosol extinction from 8.7 to $17 \%$ (Fig. S11). The SSA from the IMPROVE calculations accordingly decreased from 0.91 to 0.83 , in much better agreement with the mean measured SSA of 0.80 . We therefore recommend implementing these changes to the MEE of EC when applying the IMPROVE algorithm, particularly in polluted environments.

The contribution of EC to the total extinction is therefore considerable, despite contributing only $4 \%$ to the total aerosol mass. Major sources of EC in the NCP include coal consumption, biomass burning, and vehicle exhaust. In the context of several haze episodes in the NCP, recent modeling studies have shown that EC, as the major absorbing component of aerosols, causes local atmospheric heating and thereby exacerbates aerosol pollution by reducing the planetary boundary layer height (Ding et al., 2016; Gao et al., 2015 , 2016). The disproportionately large effect of EC observed in our study supports the suggestion in these papers that targeting the reduction of EC emissions will pay off both in improving air quality and reducing climate impacts.

\section{Summary and conclusions}

$\mathrm{PM}_{1.0}$ optical properties and composition at a suburban site near Beijing were measured during the HOPE- $\mathrm{J}^{3} \mathrm{~A}$ campaign. Six periods were investigated in detail to study the evolution of intensive optical properties and chemical composition in $\mathrm{PM}_{1.0}$ during an extended haze episode. Our analysis reveals that the optical properties of aerosols change significantly during the evolution of haze.
The mass concentrations of sulfate, nitrate, and ammonium species were high during haze episodes. Organic matter was consistently the dominant constituent by mass of the observed aerosols, and light extinction apportionment indicated that was it accordingly made the largest contribution to the extinction of $\mathrm{PM}_{1.0}$. Under polluted conditions, the proportion of inorganic components, especially nitrate, was higher than under clean conditions and the contribution of inorganic components to visibility degradation was significant.

Under polluted conditions, the average MAE of EC were up to 4 times as large as the reference MAE value for freshly emitted BC. The temporal pattern of MAE values was similar to that of the $\mathrm{OC} / \mathrm{EC}$ ratio, suggesting that some non-BC absorption from SOA also contributes to particle absorption. After considering the coating-enhanced absorption by EC, agreement with measurements was improved with the new modified IMPROVE algorithm. Organic mass was the largest contributor $(52 \%)$ to the total extinction of $\mathrm{PM}_{1.0}$, while $\mathrm{EC}$, despite its mass concentration being only $4 \%$, contributed about $17 \%$ to extinction. EC, owing to its high absorption efficiency, contributed appreciably to $\mathrm{PM}_{1.0}$ extinction and should be a key target to air quality controls.

\section{The Supplement related to this article is available online at doi:10.5194/acp-16-6421-2016-supplement.}

Acknowledgements. The authors wish to thank Zhouqing Xie at the University of Science and Technology of China for providing the meteorological data used in this paper and Jun Tao and Zejian Lin at the South China Institute of Environmental Science for helpful discussion. This research was supported by the National Natural Science Foundation of China (41330424), the Natural Science Foundation of Anhui Province (1508085J03), the Key Research Program of the Chinese Academy of Sciences (KJZDEW-TZ-G06-01), and the China Special Fund for Meteorological Research in the Public Interest (GYHY201406039). The support of the CaPPA project ("Chemical and Physical Properties of the Atmosphere"), funded by the French National Research Agency through the "Programme d'Investissement d'Avenir" (under contract ANR-10-LABX-005), is acknowledged. We thank the reviewers and editor for their constructive suggestions.

Edited by: Y. Rudich

\section{References}

Abo Riziq, A., Erlick, C., Dinar, E., and Rudich, Y.: Optical properties of absorbing and non-absorbing aerosols retrieved by cavity ring down (CRD) spectroscopy, Atmos. Chem. Phys., 7, 15231536, doi:10.5194/acp-7-1523-2007, 2007.

Anderson, T. L., Charlson, R. J., Schwartz, S. E., Knutti, R., Boucher, O., Rodhe, H., and Heintzenberg, J.: Atmospheric science. Climate forcing by aerosol - a hazy picture, Science, 300, 1103-1104, 2003. 
Andersson, A., Deng, J., Du, K., Zheng, M., Yan, C., Skold, M., and Gustafsson, O.: Regionallyvarying combustion sources of the January 2013 severe haze events over eastern China, Environ. Sci. Technol., 49, 2038-2043, doi:10.1021/es503855e, 2015.

Andreae, M. O. and Gelencsér, A.: Black carbon or brown carbon? The nature of light-absorbing carbonaceous aerosols, Atmos. Chem. Phys., 6, 3131-3148, doi:10.5194/acp-6-3131-2006, 2006.

Andreae, M. O., Schmid, O., Yang, H., Chand, D., Yu, J. Z., Zeng, L.-M., and Zhang, Y.-H.: Optical properties and chemical composition of the atmospheric aerosol in urban Guangzhou, China, Atmos. Environ., 42, 6335-6350, 2008.

Bahadur, R., Praveen, P. S., Xu, Y., and Ramanathan, V.: Solar absorption by elemental and brown carbon determined from spectral observations, P. Natl. Acad. Sci. USA, 109, 17366-17371, 2012.

Bates, T. S., Huebert, B. J., Gras, J. L., Griffiths, F. B., and Durkee, P. A.: International Global Atmospheric Chemistry (IGAC) project's first aerosol characterization experiment (ACE 1): overview, J. Geophys. Res., 103, 16297-16318, doi:10.1029/97jd03741, 1998.

Bates, T. S., Anderson, T. L., Baynard, T., Bond, T., Boucher, O., Carmichael, G., Clarke, A., Erlick, C., Guo, H., Horowitz, L., Howell, S., Kulkarni, S., Maring, H., McComiskey, A., Middlebrook, A., Noone, K., O’Dowd, C. D., Ogren, J., Penner, J., Quinn, P. K., Ravishankara, A. R., Savoie, D. L., Schwartz, S. E., Shinozuka, Y., Tang, Y., Weber, R. J., and Wu, Y.: Aerosol direct radiative effects over the northwest Atlantic, northwest Pacific, and North Indian Oceans: estimates based on in-situ chemical and optical measurements and chemical transport modeling, Atmos. Chem. Phys., 6, 1657-1732, doi:10.5194/acp-6-1657-2006, 2006.

Bond, T. C., Doherty, S. J., Fahey, D. W., Forster, P. M., Berntsen, T., DeAngelo, B. J., Flanner, M. G., Ghan, S., Kärcher, B., Koch, D., Kinne, S., Kondo, Y., Quinn, P. K., Sarofim, M. C., Schultz, M. G., Schulz, M., Venkataraman, C., Zhang, H., Zhang, S., Bellouin, N., Guttikunda, S. K., Hopke, P. K., Jacobson, M. Z., Kaiser, J. W., Klimont, Z., Lohmann, U., Schwarz, J. P., Shindell, D., Storelvmo, T., Warren, S. G., and Zender C. S.: Bounding the role of black carbon in the climate system: A scientific assessment, J. Geophys. Res.-Atmos., 118, 5380-5552, doi:10.1002/jgrd.50171, 2013.

Bond, T. C., Habib, G., and Bergstrom, R. W.: Limitations in the enhancement of visible light absorption due to mixing state, J. Geophys. Res., 111, D20211, doi:10.1029/2006JD007315, 2006.

Cahill, J. F., Suski, K., Seinfeld, J. H., Zaveri, R. A., and Prather, K. A.: The mixing state of carbonaceous aerosol particles in northern and southern California measured during CARES and CalNex 2010, Atmos. Chem. Phys., 12, 10989-11002, doi:10.5194/acp-12-10989-2012, 2012.

Cao, J., Chow, J. C., Lee, F. S. C., and Watson, J. G.: Evolution of $\mathrm{PM}_{2.5}$ measurements and standards in the US and future perspectives for china, Aerosol Air Qual. Res., 13, 1197-1211, 2013.

Cao, J. J., Wang, Q. Y., Chow, J. C., Watson, J. G., Tie, X. X., Shen, Z. X., Wang, P., and An, Z. S.: Impacts of aerosol compositions on visibility impairment in Xi' an, China, Atmos. Environ., 59, 559-566, doi:10.1016/j.atmosenv.2012.05.036, 2012.

Cappa, C. D., Onasch, T. B., Massoli, P., Worsnop, D. R., Bates, T. S., Cross, E. S., Davidovits, P., Hakala, J., Hayden, K. L.,
Jobson, B. T., Kolesar, K. R., Lack, D. A., Lerner, B. M., S. M., Mellon, D., Nuaaman, I., Olfert, J. S., Petäjä, T., Quinn, P. K., Song, C., Subramanian, R., Williams, E. J., and Zaveri, R. A. : Radiative absorption enhancements due to the mixing state of atmospheric black carbon, Science, 337, 1078-1081, doi:10.1126/science.1223447, 2012.

Chan, T. W., Brook, J. R., Smallwood, G. J., and Lu, G.: Time resolved measurements of black carbon light absorption enhancement in urban and near-urban locations of southern Ontario, Canada, Atmos. Chem. Phys., 11, 10407-10432, doi:10.5194/acp-11-10407-2011, 2011.

Cheng, Y., He, K.-B., Zheng, M., Duan, F.-K., Du, Z.-Y., Ma, Y.L., Tan, J.-H., Yang, F.-M., Liu, J.-M., Zhang, X.-L., Weber, R. J., Bergin, M. H., and Russell, A. G.: Mass absorption efficiency of elemental carbon and water-soluble organic carbon in Beijing, China, Atmos. Chem. Phys., 11, 11497-11510, doi:10.5194/acp11-11497-2011, 2011.

Cheng, Y., Engling, G., Moosmüller, H., Arnott, W. P., Chen, L. W. A., Wolde, C. E., Min Hao, W. M., and He, K. B.: Light absorption by biomass burning source emissions, Atmos. Environ., 127, 347-354, 2016.

Cheng, Y. F., Wiedensohler, A., Eichler, H., Su, H., Gnauk, T., Brüggemann, E., Herrmann, H., Heintzenberg, J., Slanina, J., Tuch, T., Hu, M., and Zhang, Y. H.: Aerosol optical properties and related chemical apportionment at Xinken in Pearl River Delta of China, Atmos. Environ., 30, 6351-6372, doi:10.1016/j.atmosenv.2008.02.034, 2008.

Cheng, Z., Jiang, J., Chen, C., Gao, J., Wang, S., Watson, J. G., Wang, H., Deng, J., Wang, B., Zhou, M., Chow, J. C., Pitchford, M. L., and Hao, J.: Estimation of aerosol mass scattering efficiencies under high mass loading: case study for the megacity of Shanghai, China, Environ. Sci. Technol., 49, 831-838, doi:10.1021/es504567q, 2015.

Cheung, H. C., Wang, T., Baumann, K., and Guo, H.: Influence of regional pollution outflow on the concentrations of fine particulate matter and visibility in the coastal area of southern China, Atmos. Environ., 39, 6463-6474, doi:10.1016/j.atmosenv.2005.07.033, 2005.

Chu, D. A., Kaufman, Y. J., Zibordi, G., Chern, J. D., Mao, J. T., Li, C. C., and Holben, B. N.: Global monitoring of air pollution over land from the Earth Observing System-Terra Moderate Resolution Imaging Spectroradiometer (MODIS), J. Geophys. Res., 108, 4661, doi:10.1029/2002JD003179, 2003.

Claeys, M., Vermeylen, R., Yasmeen, F., Gómez-González, Y., Chi, C., Maenhaut, W., Mészáros, T., and Salma, I.: Chemical characterisation of humic-like substances from urban, rural and tropical biomass burning environments using liquid chromatography with UV/vis photodiode array detection and electrospray ionisation mass spectrometry, Environ. Chem., 9, 273-284, 2012.

Cui, X., Wang, X., Yang, L., Chen, B., Chen, J., Andersson, A., and Gustafsson, Ö.: Radiative absorption enhancement from coatings on black carbon aerosols, Sci. Total Environ. 551-552, 51-56, 2016.

Di Lorenzo, R. A. and Young C. J.: Size separation method for absorption characterization in brown carbon: Application to an aged biomass burning sample, Geophys. Res. Lett., 43, 458-465, doi:10.1002/2015GL066954, 2016.

Dinar, E., Abo Riziq, A., Spindler, C., Erlick, C., Kiss, G., and Rudich, Y.: The complex refractive index of atmospheric and 
model humic-like substances (HULIS) retrieved by a cavity ring down aerosol spectrometer (CRD-AS), Faraday Discuss., 137, 279-295, 2008.

Ding, A. J., Huang, X., Nie, W., Sun, J. N., Kerminen, V.-M., Petäjä, T., Su, H., Cheng, Y. F., Yang, X.-Q., Wang, M. H., Chi, X. G., Wang, J. P., Virkkula, A., Guo, W. D., Yuan, J., Wang, S. Y., Zhang, R. J., Wu, Y. F., Song, Y., Zhu, T., Zilitinkevich, S., Kulmala, M., and Fu, C. B.: Enhanced haze pollution by black carbon in megacities in China, Geophys. Res. Lett., 43, 2873-2879, doi:10.1002/2016GL067745, 2016.

Doherty, S. J., Quinn, P. K., Jefferson, A., Carrico, C. M., Anderson, T. L., and Hegg, D.: A comparison and summary of aerosol optical properties as observed in situ from aircraft, ship, and land during ACE-Asia, J. Geophys. Res., 110, D04201, doi:10.1029/2004jd004964, 2005.

Eldering, A., Ogren, J. A., Chowdhury, Z., Hughes, L. S., and Cass, G. R.: Aerosol optical properties during INDOEX based on measured aerosol particle size and composition, J. Geophys. Res., 107, 8001, doi:10.1029/2001jd001572, 2002.

Fiedler, S. E., Hese, A., and Ruth, A. A.: Incoherent broad-band cavity-enhanced absorption spectroscopy, Chem. Phys. Lett., 371, 284-294, 2003.

Gao, M., Carmichael, G. R., Wang, Y., Saide, P. E., Yu, M., Xin, J., Liu, Z., and Wang, Z.: Modeling study of the 2010 regional haze event in the North China Plain, Atmos. Chem. Phys., 16, 1673-1691, doi:10.5194/acp-16-1673-2016, 2016.

Gao, Y., Zhang, M., Liu, Z., Wang, L., Wang, P., Xia, X., Tao, M., and Zhu, L.: Modeling the feedback between aerosol and meteorological variables in the atmospheric boundary layer during a severe fog-haze event over the North China Plain, Atmos. Chem. Phys., 15, 4279-4295, doi:10.5194/acp-15-4279-2015, 2015.

Garland, R. M., Yang, H., Schmid, O., Rose, D., Nowak, A., Achtert, P., Wiedensohler, A., Takegawa, N., Kita, K., Miyazaki, Y., Kondo, Y., Hu, M., Shao, M., Zeng, L. M., Zhang, Y. H., Andreae, M. O., and Pöschl, U.: Aerosol optical properties in a rural environment near the mega-city Guangzhou, China: implications for regional air pollution, radiative forcing and remote sensing, Atmos. Chem. Phys., 8, 5161-5186, doi:10.5194/acp-85161-2008, 2008.

Garland, R. M., Schmid, O., Nowak, A., Achtert, P., Wiedensohler, A., Gunthe, S. S., Takegawa, N., Kita, K., Kondo, Y., Hu, M., Shao, M., Zeng, L. M., Zhu, T., Andreae, M. O., and Pöschl, U.: Aerosol optical properties observed during Campaign of Air Quality Research in Beijing 2006 (CAREBeijing-2006): characteristic differences between the inflow and outflow of Beijing city air, J. Geophys. Res., 114, D00g04, doi:10.1029/2008jd010780, 2009.

Guo, S., Hu, M., Zamora, M. L., Peng, J., Shang, D., Zheng, J., Du, Z., Wu, Z., Shao, M., Zeng, L., Molina, M. J., and Zhang, R.: Elucidating severe urban haze formation in China, P. Natl. Acad. Sci. USA, 111, 17373-17378, 2014.

Gustafssona, Ö. and Ramanathan, V.: Convergence on climate warming by black carbon aerosols, P. Natl. Acad. Sci. USA, 113, 4243-4245, doi:10.1073/pnas.1603570113, 2016.

Han, B., Zhang, R., Yang, W., Bai, Z., Ma, Z., and Zhang, W.: Heavy air pollution episodes in Beijing during January 2013: inorganic ion chemistry and source analysis using Highly Time-Resolved Measurements in an urban site, Atmos. Chem. Phys. Discuss., 15, 11111-11141, doi:10.5194/acpd-15-11111-2015, 2015.
Han, L., Zhou, W., and Li, W.: Increasing impact of urban fine particles $\left(\mathrm{PM}_{2.5}\right)$ on areas surrounding Chinese cities, Scient. Rep., 5, 12467, doi:10.1038/srep12467, 2015.

Han, T. T., Liu, X. G., Zhang, Y. H., Qu, Y., Gu, J. W., Ma, Q., Lu, K. D., Tian, H. Z., Chen, J., Zeng, L. M., Hu, M., and Zhu, T.: Characteristics of aerosol optical properties and their chemical apportionments during CAREBeijing 2006, Aerosol Air Qual. Res., 14, 1431-1442, 2014.

Hand, J. L. and Malm, W. C.: Review of aerosol mass scattering efficiencies from ground-based measurements since 1990, J. Geophys. Res., 112, D16203, doi:10.1029/2007JD008484, 2007.

Hasan, H. and Dzubay, T. G.: Apportioning light extinction coefficients to chemical species in atmospheric aerosol, Atmos. Environ., 17, 1573-1581, 1983.

Huang, R. J., Zhang, Y., Bozzetti, C., Ho, K.-F., Cao, J., Han, Y., Dällenbach, K. R., Slowik, J. G., Platt, S. M., Canonaco, F., Zotter, P., Wolf, R., Pieber, S. M., Bruns, E. A., Crippa, M., Ciarelli, G., Piazzalunga, A., Schwikowski, M., Abbaszade, G., SchnelleKreis, J., Zimmermann, R., An, Z., Szidat, S., Baltensperger, U., Haddad, I. E., and Prévôt, A. S. H.: High secondary aerosol contribution to particulate pollution during haze events in China, Nature, 514, 218-222, 2014.

Jansen, R. C., Shi, Y., Chen, J., Hu, Y., Xu, C., Hong, S., Li, J., and Zhang, M.: Using hourly measurements to explore the role of secondary inorganic aerosol in $\mathrm{PM}_{2.5}$ during haze and fog in Hangzhou, China, Adv. Atmos. Sci., 31, 1427-1434, 2014.

Jung, J., Lee, H., Kim, Y. J., Liu, X. G., Zhang, Y. H., Hu, M., and Sugimoto, N.: Optical properties of atmospheric aerosols obtained by in situ and remote measurements during 2006 Campaign of Air Quality Research in Beijing (CAREBeijing-2006), J. Geophys. Res., 114, D00g02, doi:10.1029/2008jd010337, 2009.

Knox, A., Evans, G. J., Brook, J. R., Yao, X., Jeong, C. H., Godri, K. J., Sabaliauskas, K., and Slowik, J. G.: Mass absorption crosssection of ambient black carbon aerosol in relation to chemical age, Aerosol Sci. Tech., 43, 522-532, 2009.

Lack, D. A., Langridge, J. M., Bahreini, R., Cappa, C. D., Middlebrook, A. M., and Schwarz, J. P.: Brown carbon and internal mixing in biomass burning particles, P. Natl. Acad. Sci. USA, 109, 14802-14807, 2012.

Lan, Z.-J., Huang, X.-F., Yu, K.-Y., Sun, T.-L., Zeng, L.-W., and Hu, M.: Light absorption of black carbon aerosol and its enhancement by mixing state in an urban atmosphere in South China, Atmos. Environ., 69, 118-123, 2013.

Lei, Y., Zhang, Q., He, K. B., and Streets, D. G.: Primary anthropogenic aerosol emission trends for China, 1990-2005, Atmos. Chem. Phys., 11, 931-954, doi:10.5194/acp-11-931-2011, 2011.

Lim, H.-J. and Turpin B. J. : Origins of primary and secondary organic aerosol in Atlanta: Results of time-resolved measurements during the Atlanta supersite experiment, Environ. Sci. Technol., 36, 4489-4496, 2002.

Lin, P., Hu, M., Deng, Z., Slanina, J., Han, S., Kondo, Y., Takegawa, N., Miyazaki, Y., Zhao, Y., and Sugimoto, N.: Seasonal and diurnal variations of organic carbon in $\mathrm{PM}_{2.5}$ in Beijing and the estimation of secondary organic carbon, J. Geophys. Res., 114, D00G11, doi:10.1029/2008JD010902, 2009.

Liu, S., Aiken, A. C., Gorkowski, K., Dubey, M. K., Cappa, C. D., Williams, L. R., Herndon, S. C., Massoli, P., Fortner, E. C., Chhabra, P. S., Brooks, W. A., Onasch, T. B., Jayne, J. T., 
Worsnop, D. R., China, S., Sharma, N., Mazzoleni, C., Xu, L., Ng, N. L., Liu, D., Allan, J. D., Lee, J. D., Fleming, Z. L., Mohr, C., Zotter, P., Szidat, S., and Prevot, A. S. H.: Enhanced light absorption by mixed source black and brown carbon particles in UK winter, Nat. Commun., 6, 8435, doi:10.1038/ncomms9435, 2015.

Liu, X. G., Li, J., Qu, Y., Han, T., Hou, L., Gu, J., Chen, C., Yang, Y., Liu, X., Yang, T., Zhang, Y., Tian, H., and Hu, M.: Formation and evolution mechanism of regional haze: a case study in the megacity Beijing, China, Atmos. Chem. Phys., 13, 4501-4514, doi:10.5194/acp-13-4501-2013, 2013.

Lyamani, H., Olmo, F. J., and Alados-Arboledas, L.: Physical and optical properties of aerosols over an urban location in Spain: seasonal and diurnal variability, Atmos. Chem. Phys., 10, 239254, doi:10.5194/acp-10-239-2010, 2010.

Mack, L. A., Levin, E. J. T., Kreidenweis, S. M., Obrist, D., Moosmüller, H., Lewis, K. A., Arnott, W. P., McMeeking, G. R., Sullivan, A. P., Wold, C. E., Hao, W.-M., Collett Jr., J. L., and Malm, W. C.: Optical closure experiments for biomass smoke aerosols, Atmos. Chem. Phys., 10, 9017-9026, doi:10.5194/acp-10-90172010, 2010.

Malm, W. C. and Hand, J. L.: An examination of the physical and optical properties of aerosols collected in the IMPROVE program, Atmos. Environ., 41, 3407-3427, doi:10.1016/j.atmosenv.2006.12.012, 2007.

Malm, W. C., Sisler, J. F., Huffman, D., Eldred, R. A., and Cahill, T. A.: Spatial and seasonal trends in particle concentration and optical extinction in the United States, J. Geophys. Res., 99, 13471370, doi:10.1029/93jd02916, 1994.

Marley, N. A., Gaffney, J. S., Castro, T., Salcido, A., and Frederick, J.: Measurements of aerosol absorption and scattering in the Mexico City Metropolitan Area during the MILAGRO field campaign: a comparison of results from the T0 and T1 sites, Atmos. Chem. Phys., 9, 189-206, doi:10.5194/acp-9-189-2009, 2009.

Moise, T., Flores, J. M., and Rudich, Y.: Optical Properties of Secondary Organic Aerosols and Their Changes by Chemical Processes, Chem. Rev., 115, 4400-4439, 2015.

Nakayama, T., Sato, K., Matsumi, Y., Imamura, T., Yamazaki, A., and Uchiyama, A.: Wavelength and $\mathrm{NO}_{x}$ dependent complex refractive index of SOAs generated from the photooxidation of toluene, Atmos. Chem. Phys., 13, 531-545, doi:10.5194/acp-13531-2013, 2013.

Nel, A.: Atmosphere. Air pollution-related illness: effects of particles, Science, 308, 804-806, 2005.

NIOSH: NIOSH Manual of Analytical Methods; National Institute of Occupational Safety and Health: Cincinnati, OH, USA, 1996.

Pathak, R. K., Wu, W. S., and Wang, T.: Summertime $\mathrm{PM}_{2.5}$ ionic species in four major cities of China: nitrate formation in an ammonia-deficient atmosphere, Atmos. Chem. Phys., 9, 17111722, doi:10.5194/acp-9-1711-2009, 2009.

Peng, J., Hua, M., Guo, S., Du, Z., Zheng, J., Shang, D., Zamora, M. L., Zeng, L., Shao, M., Wu, Y.-S., Zheng, J., Wang, Y., Glen, C. R., Collins, D. R., Molina, M. J., and Zhang, R. : Markedly enhanced absorption and direct radiative forcing of black carbon under polluted urban environments, P. Natl. Acad. Sci. USA, 113, 4266-4271, doi:10.1073/pnas.1602310113, 2016.

Peterson, M. R. and Richards, M. H.: Thermal-opticaltransmittance analysis for organic, elemental, carbonate, total carbon, and OCX2 in $\mathrm{PM}_{2.5}$ by the EPA/NIOSH method, in: Proceedings, Symposium on Air Quality Measurement Methods and Technology-2002, San Francisco, California, 13-15 November 2002, edited by: Winegar, E. D. and Tropp, R. J., Air and Waste Management Association, Pittsburgh, PA, 83-1-83-19, 2002.

Pettersson, A., Lovejoy, E. R., Brock, C. A., Brown, S. S., and Ravishankara, A. R.: Measurement of aerosol optical extinction at with pulsed cavity ring down spectroscopy, J. Aerosol Sci., 35, 995-1011, 2004.

Pitchford, M., Malm, W., Schichtel, B., Kumar, N., Lowenthal, D., and Hand, J.: Revised algorithm for estimating light extinction from IMPROVE particle speciation data, J. Air Waste Manage., 57, 1326-1336, doi:10.3155/1047-3289.57.11.1326, 2007.

Quan, J. N., Tie, X., Zhang, Q., Liu, Q., Li, X., Gao, Y., and Zhao, D. L.: Characteristics of heavy aerosol pollution during the 2012-2013 winter in Beijing, China, Atmos. Environ., 88, 83-89, doi:10.1016/j.atmosenv.2014.01.058, 2014.

Quinn, P. K.: Aerosol optical properties measured on board the Ronald H. Brown during ACEAsia as a function of aerosol chemical composition and source region, J. Geophys. Res.-Atmos., 109, D19S01, doi:10.1029/2003JD004010, 2004.

Quinn, P. K., Coffman, D. J., Bates, T. S., Miller, T. L., Johnson, J. E., Voss, K., Welton, E. J., and Neususs, C.: Dominant aerosol chemical components and their contribution to extinction during the aerosols cruise across the Atlantic, J. Geophys. Res.-Atmos., 106, 20783-20809, doi:10.1029/2000jd900577, 2001.

Quinn, P. K., Coffman, D. J., Bates, T. S., Miller, T. L., Johnson, J. E., Welton, E. J., Neususs, C., Miller, M., and Sheridan, P. J.: Aerosol optical properties during INDOEX 1999: means, variability, and controlling factors, J. Geophys. Res.-Atmos., 107, 8020, doi:10.1029/2000jd000037, 2002.

Raes, F., Bates, T., McGovern, F., and Van Liedekerke, M.: The 2nd Aerosol Characterization Experiment (ACE-2): general overview and main results, Tellus B, 52, 111-125, doi:10.1034/j.1600-0889.2000.00124.x, 2000.

Ramanathan, V., Crutzen, P. J., Kiehl, J. T., and Rosenfeld, D.: Aerosols, Climate and the Hydrological Cycle, Science, 294, 2119-2124, 2001.

Ryerson, T. B., Andrews, A. E., Angevine, W. M., Bates, T. S., Brock, C. A., Cairns, B., Cohen, R. C., Cooper, O. R., de Gouw, J. A., Fehsenfeld, F. C., Ferrare, R. A., Fischer, M. L., Flagan, R. C., Goldstein, A. H., Hair, J. W., Hardesty, R. M., Hostetler, C. A., Jimenez, J. L., Langford, A. O., McCauley, E., McKeen, S. A., Molina, L. T., Nenes, A., Oltmans, S. J., Parrish, D. D., Pederson, J. R., Pierce, R. B., Prather, K., Quinn, P. K., Seinfeld, J. H., Senff, C. J., Sorooshian, A., Stutz, J., Surratt, J. D., Trainer, M., Volkamer, R., Williams, E. J., and Wofsy, S. C.: The 2010 California research at the nexus of air quality and climate change (CalNex) field study, J. Geophys. Res., 118, 5830-5866, doi:10.1002/Jgrd.50331, 2013.

Sun, Y. L., Wang, Z. F., Fu, P. Q., Yang, T., Jiang, Q., Dong, H. B., Li, J., and Jia, J. J.: Aerosol composition, sources and processes during wintertime in Beijing, China, Atmos. Chem. Phys., 13, 4577-4592, doi:10.5194/acp-13-4577-2013, 2013.

Sun, Y. L., Jiang, Q., Wang, Z. F., Fu, P. Q., Li, J., Yang, T., and Yin, Y.: Investigation of the sources and evolution processes of severe haze pollution in Beijing in January 2013, J. Geophys. Res.Atmos., 119, 4380-4398, doi:10.1002/2014jd021641, 2014. 
Sun, Y. L., Wang, Z. F., Du, W., Zhang, Q., Wang, Q. Q., Fu, P. Q., Pan, X. L., Li, J., Jayne, J., and Worsnop, D. R.: Longterm real-time measurements of aerosol particle composition in Beijing, China: seasonal variations, meteorological effects, and source analysis, Atmos. Chem. Phys., 15, 10149-10165, doi:10.5194/acp-15-10149-2015, 2015.

Takegawa, N., Miyakawa, T., Kuwata, M., Kondo, Y., Zhao, Y., Han, S., Kita, K., Miyazaki, Y., Deng, Z., Xiao, R., Hu, M., van Pinxteren, D., Herrmann, H., Hofzumahaus, A., Holland, F., Wahner, A., Blake, D. R., Sugimoto, N., and Zhu, T.: Variability of submicron aerosol observed at a rural site in Beijing in the summer of 2006, J. Geophys. Res., 114, D00g05, doi:10.1029/2008jd010857, 2009.

Tao, J., Ho, K. F., Chen, L. G., Zhu, L. H., Han, J. L., and $\mathrm{Xu}$, Z. C.: Effect of chemical composition of $\mathrm{PM}_{2.5}$ on visibility in Guangzhou, China, 2007 spring, Partic, 7, 68-75, doi:10.1016/j.partic.2008.11.002, 2009.

Tao, J., Zhang, L., Cao, J., Hsu, S.-C., Xia, X., Zhang, Z., Lin, Z., Cheng, T., and Zhang, R.: Characterization and source apportionment of aerosol light extinction in Chengdu, southwest China, Atmos. Environ., 95, 552-562, doi:10.1016/j.atmosenv.2014.07.017, 2014a.

Tao, J., Zhang, L., Ho, K., Zhang, R., Lin, Z., Zhang, Z., Lin, M., Cao, J., Liu, S., and Wang, G.: Impact of PM2.5 chemical compositions on aerosol light scattering in Guangzhouthe largest megacity in South China, Atmos. Res., 135, 48-58, doi:10.1016/j.atmosres.2013.08.015, 2014b.

Tao, J., Zhang, L. M., Gao, J., Wang, H., Chai, F. H., and Wang, S. L.: Aerosol chemical composition and light scattering during a winter season in Beijing, Atmos. Environ., 110, 36-44, doi:10.1016/j.atmosenv.2015.03.037, 2015.

Tian, M., Wang, H. B., Chen, Y., Yang, F. M., Zhang, X. H., Zou, Q., Zhang, R. Q., Ma, Y. L., and He, K. B.: Characteristics of aerosol pollution during heavy haze events in Suzhou, China, Atmos. Chem. Phys. Discuss., 15, 33407-33443, doi:10.5194/acpd-1533407-2015, 2015.

Tian, S. L., Pan, Y. P., and Wang, Y. S.: Size-resolved source apportionment of particulate matter in urban Beijing during haze and non-haze episodes, Atmos. Chem. Phys., 16, 1-19, doi:10.5194/acp-16-1-2016, 2016.

Thompson, J. E., Hayes, P. L., Jimenez, J. L., Adachi, K., Zhang, X., Liu, J., Weber, R. J., and Buseck, P. R.: Aerosol optical properties at Pasadena, CA during CalNex 2010, Atmos. Environ., 55, 190200, doi:10.1016/j.atmosenv.2012.03.011, 2012.

Turpin, B. J. and Lim, H. J.: Species contributions to $\mathrm{PM}_{2.5}$ mass concentrations: revisiting common assumptions for estimating organic mass, Aerosol Sci. Tech., 35, 602-610, doi:10.1080/02786820119445, 2001.

Varma, R., Moosmüller, H., and Arnott, W. P.: Toward an ideal integrating nephelometer, Opt. Lett., 28, 1007-1009, 2003.

Wang, L., Li, Z., Tian, Q., Ma, Y., Zhang, F., Zhang, Y., Li, D., Li, K., and Li L.: Estimate of aerosol absorbing components of black carbon, brown carbon, and dust from ground-based remote sensing data of sun-sky radiometers, J. Geophys. Res.-Atmos., 118, 6534-6543, doi:10.1002/jgrd.50356, 2013.

Wang, Q., Huang, R.-J., Cao, J., Han, Y., Wang, G., Li, G., Wang, Y., Dai, W., Zhang, R., and Zhou, Y.: Mixing state of black carbon aerosol in a heavily polluted urban area of China: implications for light absorption enhancement, Aerosol Sci. Tech., 48, 689697, 2014.

Wang, X., Huang, J., Zhang, R., Chen, B., and Bi, J.: Surface measurements of aerosol properties over northwest China during ARM China 2008 deployment, J. Geophys. Res., 115, D00K27, doi:10.1029/2009JD013467, 2010.

Wang, X. F., Wang, T., Pathak, R. K., Hallquist, M., Gao, X. M., Nie, W., Xue, L. K., Gao, J., Gao, R., Zhang, Q. Z., Wang, W. X., Wang, S. L., Chai, F. H., and Chen, Y. Z.: Size distributions of aerosol sulfates and nitrates in Beijing during the 2008 Olympic Games: impacts of pollution control measures and regional transport, Adv. Atmos. Sci., 30, 341-353, 2013.

Wang, Y. H., Liu, Z. R., Zhang, J. K., Hu, B., Ji, D. S., Yu, Y. C., and Wang, Y. S.: Aerosol physicochemical properties and implications for visibility during an intense haze episode during winter in Beijing, Atmos. Chem. Phys., 15, 3205-3215, doi:10.5194/acp-15-3205-2015, 2015.

Watson, J. G.: Visibility: science and regulation, J. Air Waste Manage., 52, 628-713, 2002.

Wu, Q. Z., Wang, Z. F., Gbaguidi, A., Gao, C., Li, L. N., and Wang, W.: A numerical study of contributions to air pollution in Beijing during CAREBeijing-2006, Atmos. Chem. Phys., 11, 59976011, doi:10.5194/acp-11-5997-2011, 2011.

Wu, Z. J., Zheng, J., Shang, D. J., Du, Z. F., Wu, Y. S., Zeng, L. M., Wiedensohler, A., and Hu, M.: Particle hygroscopicity and its link to chemical composition in the urban atmosphere of Beijing, China, during summertime, Atmos. Chem. Phys., 16, 11231138, doi:10.5194/acp-16-1123-2016, 2016.

Xu, J., Ma, J. Z., Zhang, X. L., Xu, X. B., Xu, X. F., Lin,W. L.,Wang, Y., Meng,W., and Ma, Z. Q.: Measurements of ozone and its precursors in Beijing during summertime: impact of urban plumes on ozone pollution in downwind rural areas, Atmos. Chem. Phys., 11, 12241-12252, doi:10.5194/acp-1112241-2011, 2011.

Xu, X., Zhao, W., Wang, S., Zhang, Q., Qian, X., Fang, B., Venables, D. S., Chen, W., Gao, X., and Zhang, W.: Retrieval of the particulate complex refractive index by using cavity enhanced aerosol albedometer, in preparation, 2016.

Yang, L. X., Wang, D. C., Cheng, S. H., Wang, Z., Zhou, Y., Zhou, X. H., and Wang, W. X.: Influence of meteorological conditions and particulate matter on visual range impairment in Jinan, China, Sci. Total Environ., 383, 164-173, doi:10.1016/j.scitotenv.2007.04.042, 2007.

Yao, T., Huang, X., He, L., Hu, M., Sun, T., Xue, L., Lin, Y., Zeng, L., and Zhang, Y.: High time resolution observation and statistical analysis of atmospheric light extinction properties and the chemical speciation of fine particulates, Sci. China Chem., 53, 1801-1808, doi:10.1007/s11426-010-4006-z, 2010.

Zhang, A., Qi, Q. W., Jiang, L. L., Zhou, F., and Wang, J. F.: Population exposure to $\mathrm{PM}_{2.5}$ in the urban area of Beijing, PLoS One, 8, e63486, doi:10.1371/journal.pone.0063486, 2013.

Zhang, H., Hu, D., Chen, J., Ye, X., Wang, X., Hao, J., Wang, L., Zhang, R., and An, Z.: Particle size distribution and polycyclic aromatic hydrocarbons emissions from agricultural crop residue burning, Environ. Sci. Technol., 45, 5477-5482, 2011.

Zhang, X., Lin, Y. H., Surratt, J. D., and Weber, R. J.: Sources, composition and absorption Angstrom exponent of light-absorbing organic components in aerosol extracts from 
the Los Angeles Basin, Environ. Sci. Technol., 47, 3685-3693, doi:10.1021/es305047b, 2013.

Zhang, Y. H., Hu, M., Zhong, L. J., Wiedensohler, A., Liu, S. C., Andreae, M. O., Wang, W., and Fan, S. J.: Regional Integrated Experiments on Air Quality over Pearl River Delta 2004 (PRIDE-PRD2004): overview, Atmos. Environ., 42, 6157-6173, doi:10.1016/j.atmosenv.2008.03.025, 2008.

Zhao, W., Dong, M., Chen, W., Gu, X., Hu, C., Gao, X., Huang, W., and Zhang, W.: Wavelengthresolved optical extinction measurements of aerosols using broad-band cavity-enhanced absorption spectroscopy over the spectral range of $445-480 \mathrm{~nm}$, Anal. Chem., 85, 2260-2268, doi:10.1021/ac303174n, 2013.

Zhao, W., Xu, X., Dong, M., Chen, W., Gu, X., Hu, C., Huang, Y., Gao, X., Huang, W., and Zhang, W.: Development of a cavityenhanced aerosol albedometer, Atmos. Meas. Tech., 7, 25512566, doi:10.5194/amt-7-2551-2014, 2014a.

Zhao, W., Xu, X., Dong, M., Chen, W., Gao, X., Huang, W., and Zhang, W.: Development of a cavity-enhanced albedometer for simultaneous measurement of aerosol extinction and scattering coefficients, in imaging and applied optics 2014, paper JTu4A.43, Propagation Through and Characterization of Distributed Volume Turbulence (pcDVT), doi:10.1364/AIO.2014.JTu4A.43, 2014b.
Zhao, X. J., Zhao, P. S., Xu, J., Meng, W., Pu, W. W., Dong, F., He, D., and Shi, Q. F.: Analysis of a winter regional haze event and its formation mechanism in the North China Plain, Atmos. Chem. Phys., 13, 5685-5696, doi:10.5194/acp-13-5685-2013, 2013.

Zheng, G. J., Duan, F. K., Su, H., Ma, Y. L., Cheng, Y., Zheng, B., Zhang, Q., Huang, T., Kimoto, T., Chang, D., Pöschl, U., Cheng, Y. F., and He, K. B.: Exploring the severe winter haze in Beijing: the impact of synoptic weather, regional transport and heterogeneous reactions, Atmos. Chem. Phys., 15, 2969-2983, doi:10.5194/acp-15-2969-2015, 2015.

Zheng, S., Pozzer, A., Cao, C. X., and Lelieveld, J.: Long-term (2001-2012) concentrations of fine particulate matter $\left(\mathrm{PM}_{2.5}\right)$ and the impact on human health in Beijing, China, Atmos. Chem. Phys., 15, 5715-5725, doi:10.5194/acp-15-5715-2015, 2015. 